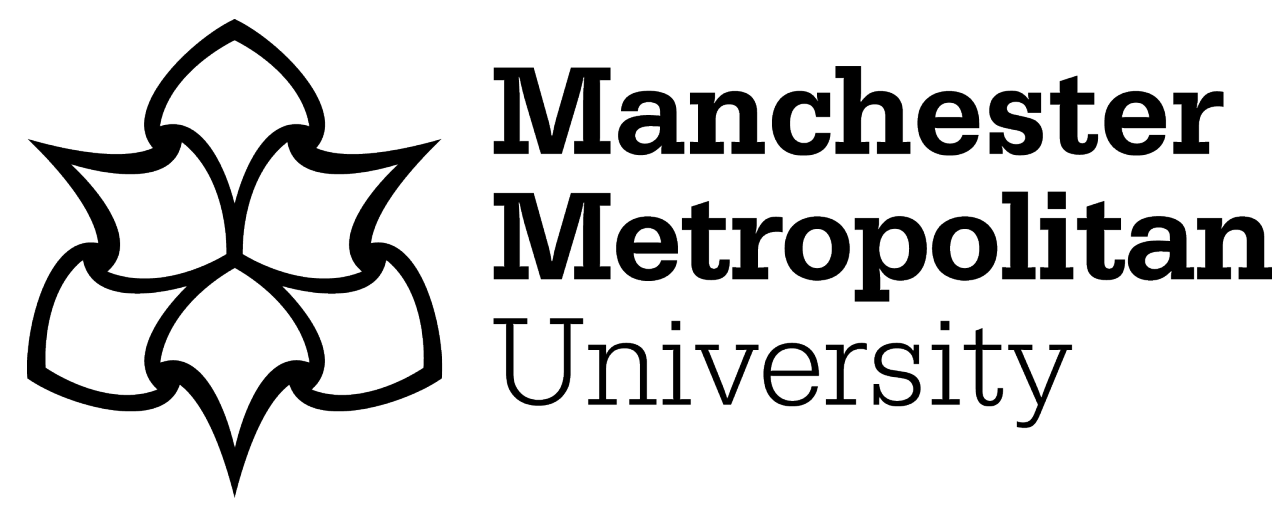

Pousti, Hamid, Urquhart, Cathy ORCID logoORCID: https://orcid.org/00000001-7754-6085 and Linger, Henry (2021) Researching the virtual: a framework for reflexivity in qualitative social media research. Information Systems Journal, 31 (3). pp. 356-383. ISSN 1350-1917

Downloaded from: https://e-space.mmu.ac.uk/626883/

Version: Accepted Version

Publisher: Wiley

DOI: https://doi.org/10.1111/isj.12314

Please cite the published version 


\title{
Researching the virtual: reflexivity in qualitative social media research
}

\begin{abstract}
Recent years have seen an explosion in social media in our everyday lives, and a corresponding increase in social media research in IS. As social media researchers, we are intrigued by the problem of virtuality and context in social media research, and how we might apply reflexive research principles to such settings. In social media, the absence of a setting's real physical boundaries (to a large extent) limits participants' ability to create a common experience at the present time and develop a history of shared experiences. As a result, we would contend that many social media researchers' interpretations of data in social media settings are often black-boxed. In this paper, we argue that many of the challenges concerned with social media settings, by nature, are emergent and linked to their virtual and contextual features. We use the Klein and Myers (1999) framework for traditional interpretive field studies as a vehicle for unpacking these challenges. We contend that these challenges may remain unnoticed if researchers do not actively reflect upon their impact on the research process. In this paper, we present a framework for social media research, considering social media research as a reflexive space, building on the notion of three levels of reflexivity: theory, design and practice. Finally, we discuss some implications of reflexivity for qualitative social media research in IS.
\end{abstract}

\section{Introduction}

Social media have become increasingly embedded in our everyday lives. In Information Systems (IS) we see a corresponding increase in research into social media, both from qualitative and quantitative perspectives. As Vaast and Walsham (2013) highlight, the interactions between new computer-based systems and networks and human and social behaviours is central to the qualitative research in IS, and for that reason, social media are important domains of inquiry for IS researchers. One thing that has intrigued us as qualitative researchers is the problem of virtuality and the context of social media in IS qualitative research. In our reading of many qualitative accounts within the IS literature, we can see that the influence of these virtual settings on researchers' interpretation of data is often blackboxed (see Appendix 1), with a little active reflection on how the setting may have affected the research. There is a dearth of deep and critical discussion on how, for instance, the virtual features of social media platforms can affect a researcher's understanding of the nature of the collected evidence and the extent the findings and conclusions of the study are relevant and useful to an identifiable audience (Robey \& Markus, 1998). In this paper, we draw on the Klein \& Myers (1999) guidance on 
interpretive field studies as a means of unpacking the various reflexive challenges of social media research.

Our concerns about the challenges of social media research are, in part, also echoed by other scholars. For example, in highlighting the challenges of studying user engagement in online forums, Vaast and Walsham (2013) and Germonprez and Hovorka (2013) call for the reconsideration of some of the underpinning methodological principles that are challenged by social media settings. Branthwaite and Patterson (2011) also highlight how social media can hinder some principal aspects of qualitative research, including a researcher's ability to develop a conversation with participants, the ability to actively listen to them, and experiencing the world from a participant's position (i.e. empathy). McKenna, Myers, and Newman (2017) also discuss how social media settings present methodological challenges to qualitative IS research and call for guidance on the most appropriate methodological approaches to the use of these research settings. In this paper, we argue that many of the challenges concerned with social media settings, by nature, are emergent and linked to their virtual and contextual features. They may remain unnoticed if researchers do not actively reflect upon their impact on the research process.

While reflexivity is largely a hidden process, and not necessarily visible in published social media studies, we would nevertheless contend that a more considered and reflexive discussion of the challenges of social media studies in IS is overdue. As Kallinikos, Aaltonen, and Marton (2013) highlight, the steady change and transfiguration of digital artifacts such as social media calls for rethinking some of the traditional assumptions in IS research and practice.

Central to this argument is that reflexivity is more than just a mechanism for honesty or management of the research experience. Alvesson and Sköldberg (2017) argue that it is a reflexive researchers' responsibility to make evident the assumptions they made for the conduct of their qualitative (interpretative) studies, and they bemoan the lack of clarity in management studies on this issue. Reflexivity is an important vehicle that enables the researcher to stay critically engaged and self-aware throughout the study and gain a richer and more "connected" knowing (Gilgun, 2008). It is the 'incarnation' of epistemology in which the constant presence of the researcher (i.e. knower) is traceable (Probst, 2015). In our own discipline, Information Systems, Weber (2003) argues for the farreaching applicability of reflexivity for socio-technical research, regardless of methodology.

That said, reflexivity has not often been explicitly discussed in IS research (Brooks, Atkinson, \& Wainwright, 2008; Ellway \& Walsham, 2015; Weber, 2003). In fact, despite the emergence of a 'reflexive turn' within overlapping disciplines such as organisational studies (e.g. Golds \& Kay, 2010), sociology (e.g. Mauthner \& Doucet, 2003) and feminist studies (e.g. Archer, 2010), IS researchers are 
as yet offered little guidance on how to identify, articulate and take into account the range of influences shaping their research as they rely on new technologies such as social media.

This paper offers a starting point to engage with reflexivity at both theoretical and practical levels and treat it as a visible aspect of qualitative social media research. In so doing, we draw on the existing literature of reflexivity, for example, from disciplines such as organisational studies, sociology and feminist studies to understand how they are tackling the same challenges. This paper, therefore, intends to answer the following question:

What are the implications of reflexivity for IS qualitative social media research?

To answer this question, this paper presents a framework for reflexivity, which, together with some considerations, aims to deepen our understanding of the implications of social media settings for qualitative research. Such an understanding can surface methodological issues that are easily overlooked in the rush to utilise the attractive research opportunities offered by social media settings. The framework presented in this paper contributes to the current debate on reflexivity by highlighting broader methodological considerations that encompass the theoretical orientation of a research study, its planning and design, and its associated research practices.

Our framework should be of interest to researchers who are directly or indirectly involved with social media research. We hope the discussion presented in this paper can stimulate further reflection and debate on the important subject of the challenges associated with the increasing use of virtual settings in IS qualitative research.

The paper is organised into the following sections. In Section 2, we discuss the challenges of social media qualitative research and highlight the underlying reasons for those challenges using Klein and Myers (1999) as a jumping-off point. Section 3 synthesises literature from multiple disciplines to present key concepts of reflexivity and highlight debates as reflected in various disciplines. Next, in Section 4, we present our framework and consider social media research as a reflexive space, building on the notion of three levels of reflexivity: theory, design and practice. We also present some considerations for social media researchers. Finally, in our concluding Section 5, we discuss the implications of reflexivity for qualitative social media research in IS.

\section{The Challenges of Social Media Qualitative Research}

The current literature about the challenges of social media settings for qualitative research is very fragmented and unstructured. To help us gain a more holistic view of such challenges, we use Klein and Myers' (1999) principles of qualitative interpretative studies to help us unpack the challenges of 
social media research. Klein and Myers' criteria stem from the concept of Hermeneutic circle that brings the significance of 'text' as the source of data to the fore of qualitative research. The philosophy of hermeneutics, based as it is in the study of ancient biblical texts (so the reader could truly hear the word of God), focuses on the meanings of texts. While Klein and Myers focus on interpretive qualitative research, it is important to note that not all qualitative social media research will be interpretive in nature. Nevertheless, the principles represent an important jumping-off point for a consideration of reflexivity that we believe will apply to all qualitative social media research. Characterising social media as a set of 'digital text(s)' (Vaast \& Urquhart, 2017) enabled us to use Klein and Myers' criteria as a high-level lens to examine different aspects of social media studies across different qualitative methods.

From a qualitative research viewpoint, 'context' is known as the circumstances and boundaries in which findings of a study have meanings (Lincoln, Lynham, \& Guba, 2018). These circumstances determine the extent of the validity of research findings and the relevance of conclusions that are drawn (Davison \& Martinsons, 2016). By understanding the characteristics and nature of such circumstances, researchers can make a distinction between the observed data and the context that gives rise to that data. In a qualitative study, many demarcations between data and context are dependent on how social relations, cultural norms, and political conditions are commonly experienced within particular physical settings.

Our consideration of the Klein and Myers (1999) principles in qualitative social media research, shown in Table 1, reveal several challenges. When considering the principle of the hermeneutic circle, it is harder in social media to see the relationships between the part and the whole, because the parts (or texts) are too fragmented. One possibility is to interview people in offline settings as well as gather data from the virtual space itself. Secondly, the principle of contextualisation is possibly the largest challenge for social media researchers. The lack of context inherent in social media settings deprives the researcher of the opportunity of providing a clear description of the historical context of the research setting. To compound the difficulty, that context is often malleable and shifting. This is not to say that social media researchers should not strive for contextualisation of their studies, rather that it may be more challenging. A study of tweets around a political event such as the Arab Spring (Hermida, Lewis, \& Zamith, 2014; Oh, Eom, \& Rao, 2015), for instance, would be improved by some historical and social explanation of those events, in order to help the readers understand the tweets themselves. At the same time, coming up with an explanation of the context is more challenging without the participants themselves. Thirdly, on the principle of interaction between the researcher and participant, most interactions in social media are electronically mediated, and many are asynchronous. As a result, positioning researchers and participants in a shared context that makes the 
co-construction of meaning possible is a difficult task. With regard to principle four, abstraction and generalisation, one perspective we can take is that the diversity of social media, and the limited or complete absence of context in most platforms makes it is difficult to claim generalisability, as it is often unclear how far findings of a study can (reasonably) be extended (Davison \& Martinsons, 2016). With regard to dialogical reasoning, the fifth principle, comprising sensitivity to the theoretical conceptions of the study and the actual findings, we would contend that social media data is malleable and fragmented, making it more difficult to identify a clear analytical storyline. As social media is a new and evolving phenomenon, it is more likely to confound theoretical preconceptions. On the issue of multiple interpretations, principle six, we would contend that the nature of social media makes it harder to understand how similar or conflicting narratives are influenced by the social context. Finally, on the seventh principle of suspicion, we would contend that biases and distortions in social media narratives are very difficult to detect due again to the difficulty of ascertaining social context. This is not say we should not try, or that this is not a vitally important principle for social media researchers - we only have to look at the role of algorithms on social media or the Cambridge Analytica scandal (Cadwalladr \& Graham-Harrison, 2018) to understand that this issue of distortion is most important.

As Table 1 highlights, there is a methodological tension between qualitative studies where physical boundaries of the setting are evident and studies where settings, due to their virtual nature, have malleable boundaries and erratic context. In social media, the absence of a setting's real physical boundaries (to a large extent) limits participants' ability to create a common experience at the present time and develop a history of shared experiences. This means that the discourse informed by the virtuality of social media can constantly shift. As such, we argue that the tension demonstrated in Table 1 has its roots in ways that the contexts of social media settings are understood, judged, studied, and communicated differently by researchers. Therefore, reflecting on the contextual aspects of social media, and communicating them, enables researchers to clearly convey the meaning of their findings and elucidate the breadth and relevance of drawn conclusions. 
Table 1. Challenges of Social Media Qualitative Research

\begin{tabular}{|c|c|c|c|c|}
\hline Principle & Description & $\begin{array}{c}\text { Example of Traditional } \\
\text { Settings }\end{array}$ & $\begin{array}{c}\text { Example of Social Media } \\
\text { studies }\end{array}$ & $\begin{array}{c}\text { Challenge/tension in Social Media- } \\
\text { Qualitative Research }\end{array}$ \\
\hline $\begin{array}{l}\text { Hermeneutic } \\
\text { Circle }\end{array}$ & $\begin{array}{l}\text { Human understanding is } \\
\text { achieved by iterating } \\
\text { between considering the } \\
\text { interdependent meaning } \\
\text { of parts and the whole that } \\
\text { they form. Going through } \\
\text { the hermeneutic circle, the } \\
\text { researcher needs to see } \\
\text { and understand the link } \\
\text { and relations between the } \\
\text { part and the whole. This } \\
\text { means that the boundaries } \\
\text { of the whole and the } \\
\text { context of the part should } \\
\text { be clearly identifiable }\end{array}$ & $\begin{array}{l}\text { Diaz Diaz Andrade and Doolin } \\
\text { (2016) study of ICT in the } \\
\text { social inclusion of refugees } \\
\text { represents a classic example of } \\
\text { using the Hermeneutic Circle } \\
\text { to understand the meaning of } \\
\text { social inclusions and the role } \\
\text { of technology across multiple } \\
\text { groups }\end{array}$ & $\begin{array}{l}\text { Branthwaite and Patterson (2011) } \\
\text { study of different social media } \\
\text { platforms such as Facebook, } \\
\text { Twitter, and Myspace show that } \\
\text { social media by its very nature is a } \\
\text { challenging space for the accurate } \\
\text { understanding and interpreting } \\
\text { meanings, attitudes and } \\
\text { motivations. }\end{array}$ & $\begin{array}{l}\text { In social media, parts (mostly texts) are too fragmented, } \\
\text { and there is a large distance between the source of the } \\
\text { observation and the boundaries of the whole. These } \\
\text { boundaries may not be fixed, and they can move in time. } \\
\text { Any iteration between parts and the whole could be very } \\
\text { challenging or even impossible. One way that } \\
\text { researchers might attempt to resolve this is by } \\
\text { interviewing people in offline settings as well as studying } \\
\text { the virtual space itself. }\end{array}$ \\
\hline Contextualisation & $\begin{array}{l}\text { Researchers must critically } \\
\text { reflect on the social and } \\
\text { historical context and } \\
\text { background of the } \\
\text { research setting to show } \\
\text { the intended audience } \\
\text { how the current situation } \\
\text { under investigation } \\
\text { emerged. }\end{array}$ & $\begin{array}{l}\text { In a study of environmentally } \\
\text { sustainable business practices, } \\
\text { Seidel, Recker, and Vom } \\
\text { Brocke (2013) applied this } \\
\text { principle to interpret their } \\
\text { findings within the context of a } \\
\text { global software company. }\end{array}$ & $\begin{array}{l}\text { By introducing the concept of a } \\
\text { digital text, Vaast and Urquhart } \\
\text { (2017), highlight how the lack of } \\
\text { social media context can challenge } \\
\text { different aspect of qualitative } \\
\text { research including the design of a } \\
\text { study and the way findings are } \\
\text { reported and represents. }\end{array}$ & $\begin{array}{l}\text { Social media's lack of (clear) context deprives the } \\
\text { researcher of the opportunity to provide a clear } \\
\text { description of the historical context of the research } \\
\text { setting. It is much more difficult for the researcher to } \\
\text { demonstrate how the results are influenced by the total } \\
\text { history of the research setting and how the research } \\
\text { influences the future of the setting. One might argue } \\
\text { that, for instance, a bunch of political tweets could easily } \\
\text { be contextualised. Such a context, however, consists of } \\
\text { social and physical boundaries which are malleable and } \\
\text { shifting, Other sources of information that aid } \\
\text { contextualisation such as media and the press may be } \\
\text { both incomplete and/or unavailable. This is not to say } \\
\text { that context should not be supplied in social media }\end{array}$ \\
\hline
\end{tabular}




\begin{tabular}{|c|c|c|c|c|}
\hline & & & & $\begin{array}{l}\text { research to help interpretation of findings, rather that it } \\
\text { can be more challenging. }\end{array}$ \\
\hline $\begin{array}{l}\text { Interaction } \\
\text { Between the } \\
\text { Researchers and } \\
\text { the participants }\end{array}$ & $\begin{array}{l}\text { Researchers must critically } \\
\text { reflect on how the } \\
\text { research materials (or } \\
\text { "data") were socially } \\
\text { constructed through the } \\
\text { interaction between the } \\
\text { researchers and } \\
\text { participants. }\end{array}$ & $\begin{array}{l}\text { Horner Reich and Benbasat } \\
\text { (2000) applied this principle to } \\
\text { investigate the influence of } \\
\text { several factors on the social } \\
\text { dimension of alignment } \\
\text { between information } \\
\text { technology (IT) and } \\
\text { organisational objectives. }\end{array}$ & $\begin{array}{l}\text { Seitz (2015) highlights the issue of } \\
\text { 'body' in qualitative research of } \\
\text { online environments and shows } \\
\text { that qualitative research is } \\
\text { corporal, and values such as trust, } \\
\text { truth, and equity are explicitly } \\
\text { linked to the corporeality of } \\
\text { qualitative research - the idea } \\
\text { that these values are embodied by } \\
\text { a physical human. } \\
\text { However, communicating and } \\
\text { sensing these values are not easily } \\
\text { done in online environments. }\end{array}$ & $\begin{array}{l}\text { Most interaction in social media is electronically } \\
\text { mediated, and predominantly asynchronous. As a } \\
\text { result, positioning researchers and participants in a } \\
\text { shared context, where the co-construction of meaning } \\
\text { possible, is a difficult task. Exchanging words that are } \\
\text { complemented with contextual information is very } \\
\text { difficult. }\end{array}$ \\
\hline $\begin{array}{l}\text { Abstraction and } \\
\text { Generalisation }\end{array}$ & $\begin{array}{l}\text { Relating the data } \\
\text { interpretation to } \\
\text { theoretical and general } \\
\text { concepts that describe the } \\
\text { nature of human } \\
\text { understanding and social } \\
\text { action. }\end{array}$ & $\begin{array}{l}\text { In their study of the role of ICT } \\
\text { in empowering rural } \\
\text { communities, Leong, Pan, } \\
\text { Newell, and Cui (2016) } \\
\text { demonstrate how the principle } \\
\text { of abstraction and } \\
\text { generalisation allow them to } \\
\text { use the existing theoretical } \\
\text { lens as a "sensitising device" to } \\
\text { analyse their empirical data } \\
\text { and view the world in a certain } \\
\text { way so they could generalise } \\
\text { their finding to theories of } \\
\text { empowerment. }\end{array}$ & $\begin{array}{l}\text { Leonardi (2014) study of } \\
\text { communication visibility in } \\
\text { organisations represents a clear } \\
\text { example of the difficulties in } \\
\text { generalising the findings to } \\
\text { different social media platforms } \\
\text { and different social contexts. } \\
\text { Many of the findings are valid for } \\
\text { a particular platform only, } \\
\text { because of the way distinct } \\
\text { technological affordances might } \\
\text { influence behaviour. }\end{array}$ & $\begin{array}{l}\text { Given the diversity of social media and the limited } \\
\text { context, or even its absence, it is difficult to claim } \\
\text { generalizability as it is often unclear how far findings of } \\
\text { a study can (reasonably) be extended (Davison \& } \\
\text { Martinsons, 2016). }\end{array}$ \\
\hline $\begin{array}{l}\text { Dialogical } \\
\text { Reasoning }\end{array}$ & $\begin{array}{l}\text { Sensitivity to possible } \\
\text { contradictions between } \\
\text { the theoretical }\end{array}$ & $\begin{array}{l}\text { The principle of dialogical } \\
\text { reasoning is used by Qureshi, } \\
\text { Kamal, and Wolcott (2009) to }\end{array}$ & $\begin{array}{l}\text { In their study of social media in } \\
\text { organisations, Scott and } \\
\text { Orlikowski (2014), highlight how }\end{array}$ & $\begin{array}{l}\text { Data is malleable, fragmented, and has limited or no } \\
\text { context. It is difficult to identify a clear story within the } \\
\text { data that can be compared or contrasted with the }\end{array}$ \\
\hline
\end{tabular}




\begin{tabular}{|c|c|c|c|c|}
\hline & $\begin{array}{l}\text { preconceptions guiding } \\
\text { the research design and } \\
\text { actual findings ("the story } \\
\text { which the data tell") with } \\
\text { subsequent cycles of } \\
\text { revision. }\end{array}$ & $\begin{array}{l}\text { analyse how context-sensitive } \\
\text { assistance enables micro- } \\
\text { entrepreneurs to overcome } \\
\text { some of the technical and } \\
\text { social barriers that they face. }\end{array}$ & $\begin{array}{l}\text { the virtual nature of social media } \\
\text { challenged their ability of } \\
\text { theorising 'anonymous reviewing } \\
\text { and rating' through the lens of } \\
\text { sociomaterial entanglement. }\end{array}$ & $\begin{array}{l}\text { theoretical preconception and it is not easy to paint a } \\
\text { clear image of the story. Furthermore, the social media } \\
\text { phenomenon itself may confound any theoretical } \\
\text { preconceptions we have. }\end{array}$ \\
\hline $\begin{array}{l}\text { Multiple } \\
\text { Interpretations }\end{array}$ & $\begin{array}{l}\text { Sensitivity to possible } \\
\text { differences in } \\
\text { interpretations among the } \\
\text { participants as are } \\
\text { typically expressed in } \\
\text { multiple narratives or } \\
\text { stories of the same } \\
\text { sequence of events under } \\
\text { study. }\end{array}$ & $\begin{array}{l}\text { In their study of the concept of } \\
\text { information systems failure, } \\
\text { Dwivedi et al. (2015) apply this } \\
\text { principle to show that within } \\
\text { organisation interpretation of } \\
\text { every IT implementation is } \\
\text { different, and no two contexts } \\
\text { can ever be exactly the same. }\end{array}$ & $\begin{array}{l}\text { By reflecting on the role of social } \\
\text { media in studying anti-vaccine } \\
\text { parents, Reich (2015) } \\
\text { demonstrates how the virtuality } \\
\text { of social media challenged the } \\
\text { researcher's ability to understand } \\
\text { and incorporate participants' } \\
\text { different interpretations and } \\
\text { narratives of the research process } \\
\text { and its objectives. }\end{array}$ & $\begin{array}{l}\text { A lack of context in social media studies and the } \\
\text { virtuality of these platforms make it rather difficult, if } \\
\text { not impossible, to understand how similar or } \\
\text { conflicting narratives are influenced by the social } \\
\text { context in which the stories emerged. It is very difficult } \\
\text { to trace events in social media as links between pieces } \\
\text { of data and sequence of events are not easily } \\
\text { identifiable. This is not to say that multiple } \\
\text { interpretations should not be sought, but that the lack } \\
\text { of social context makes those multiple interpretations } \\
\text { harder to evaluate. }\end{array}$ \\
\hline Suspicion & $\begin{array}{l}\text { Sensitivity to possible } \\
\text { "biases" and systematic } \\
\text { "distortions" in the } \\
\text { narratives collected from } \\
\text { the participants The } \\
\text { researcher role is to go } \\
\text { beyond understanding the } \\
\text { meaning of the data and } \\
\text { to intimately engage in a } \\
\text { conversation with the } \\
\text { participants to understand } \\
\text { biases the exists in the } \\
\text { social context behind } \\
\text { words/text. }\end{array}$ & $\begin{array}{l}\text { Roulston and Shelton (2015) } \\
\text { studies of students in } \\
\text { classroom settings show how } \\
\text { reflection on biases and } \\
\text { relationships enabled them to } \\
\text { more transparent and honest } \\
\text { about their findings and their } \\
\text { interpretation of data. }\end{array}$ & $\begin{array}{l}\text { Germonprez and Hovorka's (2013) } \\
\text { study of Digg and Twitter } \\
\text { highlights problems inherent in } \\
\text { researching social media shows } \\
\text { how gaining a deep understanding } \\
\text { of meanings is challenged by the } \\
\text { collected online data from social } \\
\text { media as the researcher was not } \\
\text { able to understand participants' } \\
\text { assumptions and biases. }\end{array}$ & $\begin{array}{l}\text { The virtuality of social media challenges the possible } \\
\text { ways that the researcher could unpack and understano } \\
\text { influential forces such as power structures, vested } \\
\text { interests, and (limited) resources and the way they can } \\
\text { shape or inform participants' biases and distortions. } \\
\text { Again, this is not to say we should not seek to be } \\
\text { sensitive to biases and distortions when researching } \\
\text { social media, rather that our research designs may } \\
\text { have to be different in order to achieve this. }\end{array}$ \\
\hline
\end{tabular}




\section{Reflexivity: gazing inward from inside}

Reflexivity in information systems research has a checkered history. Early works that demonstrate aspects of reflexivity in IS research can be traced back to Mathiassen's (1998) work about reflective practice. In his work, Mathiassen adopts a reflexive view to critique the process and practice of systems development as described by Nunamaker Jr, Chen, and Purdin (1990). By adopting a reflexive position, Mathiassen showed a novel approach to unpacking and questioning the established practice of systems development. Following Mathiassen, Schultz's (2000) confessional study of knowledge workers enriched IS literature by providing a prominent example of reflexivity in IS qualitative research. Schultz offered a compelling account of how self-reflexivity enables researchers to understand the intricacies of a qualitative study and reflect on issues that prevent consideration of alternative interpretations of data. Following these two important works, a serious call for reflexivity in IS was made in 2003, when the chief editor of MIS Quarterly at the time called for more evidential reflexivity in IS research (Weber, 2003). Since then, reflexivity in IS studies has received some attention but has not been positioned as an explicit and essential aspect of qualitative research. With a few exceptions where reflexivity is traceable (e.g. Baird, Davidson, \& Mathiassen, 2017; Yang, Hsu, Sarker, \& Lee, 2017), this gap is even more evident in the IS social media literature. That said, in the last few years, there have been some calls for reflexivity in IS social media research in particular (e.g. Germonprez and Hovorka, 2013) and some increase in reflective studies in general. Most current studies take a critical view of IS (e.g. De Vaujany, Walsh, \& Mitev, 2011) and focus on the personal self-reflexivity (e.g. Turel, 2016) or methodological reflexivity (e.g. Kallinikos et al., 2013). As Malaurent and Avison (2017) point out, these works have provided IS researchers with a basis to recognise the significance of reflexivity and its contribution to the rigour and quality of their qualitative research.

As the literature suggests, reflexivity is a multifaceted concept, and across different disciplines, it is recognised by various meanings and definitions (Probst \& Berenson, 2014). For example, in defining reflexivity, Finlay (2002) adopts a methodological view, describing reflexivity as a thoughtful approach to personal dynamics, accompanied by critical self-awareness of how dynamic relationships between researcher and research participants affect the process and outcomes of a study. Following Bourdieu's epistemological argument about cultural capital (Bourdieu, 1990), Archer (2010) defines reflexivity as an internal dialogue that reveals the causal power of individuals' actions in research. In IS, for example, Ellway and Walsham (2015) take an ontological perspective by conceptualising 
reflexivity through the lens of Giddens' (1984) structuration theory, and describe it as the mental capability of agents in relation to their immediate social context (that is, structure) in which they operate. A key element to these definitions is that reflexivity is a concept that is commonly discussed across different disciplines, but exercised differently (Caetano, 2015). Finlay (2002) argues that reflexivity is now an inseparable aspect of qualitative research practice and that researchers no longer question the need for reflexivity - instead, the real question is how to do it.

In general, reflexivity is described as the understanding and acknowledgement of a researcher's subjectivity, and the articulation of how the researcher's biases may affect the research process. It is also an awareness of how the research process can affect the researcher's biases (Gough \& Finlay, 2003; Pillow, 2015). In short, reflexivity is the endeavour of making transparent the complex relationship between researcher and research process and understanding the implications of such a relationship for the research outcome.

According to Pillow (2003), what makes reflexivity a debated concept, and subsequently, a complex process, is how it is theoretically positioned within qualitative research. For instance, in IS, discussion about reflexivity is mostly informed by theoretical views that are based on structuration theory (e.g. Ellway \& Walsham, 2015), actor-network theory (ANT) (e.g. Brooks et al., 2008) and critical realism (e.g. De Vaujany, 2008), with each presenting a distinct take on reflexivity and how it can be operationalised.

Our reading of the literature suggests that this debate exists at many levels. At the epistemological level, most debates about reflexivity intersect with questions surrounding representation and legitimisation of qualitative research (for example, Pillow, 2003). The complexity of reflexivity at the ontological level, as Gemignani (2016) discusses, is rooted in the existing tensions between different theoretical perspectives such as realists, humanists or feminists, as each suggests its own distinct way that reflexivity can be understood and operationalised. Archer (2010) explains that because of this diversity, reflexivity is bound to be problematic for qualitative studies. This is particularly evident in interdisciplinary and multidisciplinary fields (such as IS) as different interpretations of the term 'reflexivity' among researchers provide them with distinct understandings of their methodological decisions.

This diversity is acknowledged within the contemporary discourse on reflexivity by many scholars who have tried to identify and synthesise different aspects of reflexivity into a number of typologies. 
These typologies aim to highlight how reflexivity can be understood and operationalised at different stages of qualitative research. For instance, Finlay (2012) offers a five-level typology for reflexivity: strategic reflexivity, contextual-discursive reflexivity, embodied reflexivity, relational reflexivity, and ethical reflexivity. On the other hand, Archer (2010) defines four modes of reflexivity as communicative, autonomous, meta and fractured. For Willig (2001) and Dowling (2006), reflexivity is mostly concerned with incorporating both epistemological and personal perspectives of researchers and research participants into the design of a study. At the epistemological level, Gough's (2003) typology makes a distinction between realist and postmodern ways of thinking about reflexivity. Gemignani (2016) expands this view by arguing for a distinction in the use of reflexivity in different research paradigms. For example, the realist use of reflexivity utilises researcher confessions as the basis of validity and authenticity of research, while the humanist version places the individuality and humanness of the researcher at the core of the inquiry. In contrast, postmodern-relativism reflexivity aims to shift the focus from questions of correspondence between description and reality to matters of practice and doing (Gemignani, 2016).

One possible way of understanding these various and diverse typologies of reflexivity is to organise this diversity into three simple categories: (1) reflexivity as a theoretical position; (2) reflexivity as a fabric of research design; and (3) reflexivity as a way of informing research practice and application. While this alternative classification is not exhaustive, it offers a useful analytical lens through which reflexivity can be understood and operationalised during the conduct of a qualitative study. This view acknowledges that in every qualitative study, both the process and product of the research endeavour is influenced by the researcher's decisions (Chughtai \& Myers, 2017); therefore, reflexivity needs to be considered on multiple levels within a study (Etherington, 2007). Furthermore, this categorisation is not geared toward any specific epistemological position, but it acknowledges the plurality of existing views toward reflexivity. In other words, regardless of epistemological position, we need to realise that our interpretation of research outcomes could differ if we question each stage of the research process, from the formation of our research foci to choices we make regarding research settings, data collection and data analysis. This is particularly important when our major sources of empirical data come from social media contexts. Table 2 presents an overview of our threelayered approach to reflexivity. 


\begin{tabular}{|c|c|}
\hline Level of reflection & Objective of reflection \\
\hline 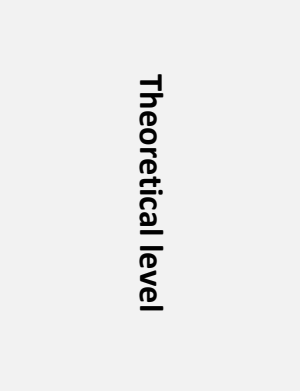 & $\begin{array}{l}\text { The focus of reflexivity at this level is on the ways that the use of social media } \\
\text { sources may influence a researcher's epistemological and ontological views } \\
\text { toward empirical evidence and the researcher's approach to understanding } \\
\text { collected data. At this level, researchers can reflect on issues concerned with } \\
\text { contextualisation, abstraction and generalisability of their findings (Davison } \\
\text { \& Martinsons, 2016; Lee \& Baskerville, 2003) and the possibility of co- } \\
\text { interpretation of data in social media (Dowling, 2006; Klein \& Myers, 1999). } \\
\text { The outcome of this level enables researchers to have a better understanding } \\
\text { of the theoretical position of their studies. }\end{array}$ \\
\hline 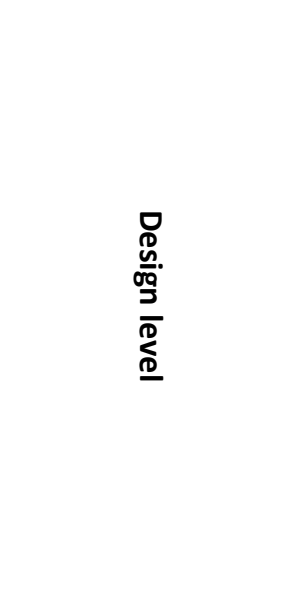 & $\begin{array}{l}\text { At this level, the focus of reflexivity aims at helping researchers to better } \\
\text { understand how a conceptual design of a qualitative study may be influenced } \\
\text { by the characteristics of social media sources. Researchers can reflect on the } \\
\text { boundaries of what they want to study, and how those boundaries may } \\
\text { affect their ability to contextualise their findings (Davison \& Martinsons, } \\
2016 ; \text { Walsham, 1995). The idea of 'where to play' must be clearly identified } \\
\text { (Ackerly \& True, 2008; Christians, 2011) in the design stage, to know what } \\
\text { gets to count as a case and what becomes context to the case (Flyvbjerg, } \\
2011 ; \text { Vaast \& Urquhart, 2017). Researchers can reflect on the nature and } \\
\text { purpose of their studies and seek relevant sources of data accordingly. Does } \\
\text { social media provide the relevant and right type of data that are in line with } \\
\text { the objectives of the study? (Miles \& Huberman, 1994). Reflexivity at this } \\
\text { level enables researchers to plan for the conduct of studies that takes into } \\
\text { account the characteristics of their social media settings. }\end{array}$ \\
\hline 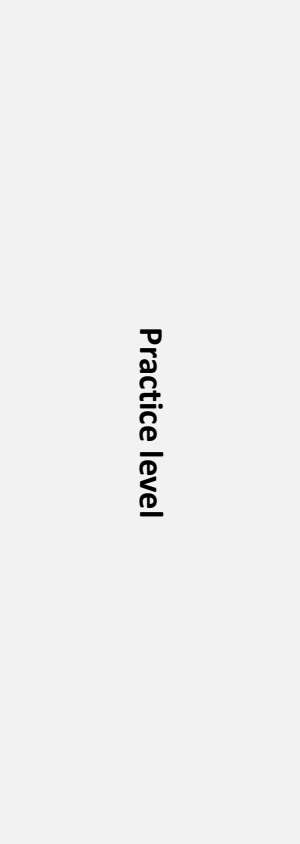 & $\begin{array}{l}\text { Reflexivity at this level seeks an understanding of the implications of social } \\
\text { media sources for the nature of data and the iterative process of qualitative } \\
\text { data collection. It also aims to aid researchers to understand the implications } \\
\text { of social media sources for ethical data collection, data analysis and } \\
\text { reporting of a qualitative social media study. Researchers can reflect on the } \\
\text { ethical issues of the study and, for instance, consider whether getting } \\
\text { informed consent applies to their study, and whether their institutional/local } \\
\text { regulations require informed consent from social media participants } \\
\text { (Moreno, Goniu, Moreno, \& Diekema, 2013). What are the implications for } \\
\text { their participants, and the institutions the researchers work at, if they cannot } \\
\text { obtain (informed) consent? Institutions may have different ethical } \\
\text { requirements (for example, some may not require researchers to obtain } \\
\text { consent from social media users). Researchers should reflect on these issues } \\
\text { and think of the implications for the conduct of their studies (Silverman, } \\
\text { 2010). Other issues such as privacy and confidentiality (Marshall \& Rossman, } \\
\text { 2011; Vaast \& Walsham, 2013) or the researchers' ability to explore and } \\
\text { contextualise the constitution of objects and participants in their historical } \\
\text { contexts (Markham, 2008) are other issues to reflect upon. Reflexivity at this } \\
\text { level enables researchers to understand the characteristics of SM settings } \\
\text { and engage with them. }\end{array}$ \\
\hline
\end{tabular}




\subsection{Reflexivity in Social Media Studies}

The current debate about social media and reflexivity in the literature, from across various disciplines, can be grouped into three major streams. In the first group, the relation between social media and reflexivity is depicted more as a causal relationship. Discussions in this stream are mainly pointing to characteristics or affordances of social media that can instigate reflection on the behaviour of actors. For instance, a study by Cooky, Linabary, and Corple (2018) shows that using social media as a source of Big Data calls for a need to reflect on institutions' regulative power and how it can affect our understanding of Big Data. In the same vein, Young and Nichols (2017) discuss how reflecting on affordances of social media enabled an understanding of the opportunities and challenges of strategic use of digital technologies in higher education learning.

The second stream is mainly concerned with the ethical issue of social media and aims to reflect on ethical implications of using social media for research and practice. This stream covers a wide range of ethical issues that may arise in research (e.g. D'Angelo \& Ryan, 2019; Zimmer \& Proferes, 2014) or in professional settings such as organisation (e.g. Kennedy \& Moss, 2015). Discussions about reflexivity and the ethical implications of social media seem to be more discipline-specific discussions and as a result, present a less converging discourse (see Housley et al., 2014). However, the common theme is that social media calls for the significance of ethical reflexivity in both research and practice.

The third stream recognises and treats social media as a space for reflexivity. Two approaches are often adopted by researchers here: social media as a facilitator for reflexivity, and social media as a reflexive space. In the first approach, social media is recognised as an environment that facilitates communication and provides opportunities for thinking about reflexivity (e.g. Numerato, Vochocová, Štětka, \& Macková, 2019). Sensitive topics such as health, privacy, power, or relationships are the main issues that are discussed within this approach and many authors argue that without access to social media, it would be nearly impossible to collaboratively and fruitfully reflect on many of these topics (e.g. Lengel \& Newsom, 2014; Stæhr, 2015).

In the second approach, social media itself is treated as a reflexive space. This space presents a set of characteristics that can affect the process and outcomes of practice, and therefore, it calls for reflexivity (e.g. Mortensen, Allan, \& Peters, 2017). In the next section, we discuss and elaborate on how we used this concept in our framework. 


\subsection{Social media as a reflexive space}

According to Alencar, Aron, and Dineen (1984), a reflexive space is an abstract concept that represents a non-linear environment with multiple dimensions where traditional assumptions about the nature of an object (e.g. its duality) can be questioned and understood differently. In such a space, the boundaries are constantly reshaped through interaction between objects and observers (Kalton, 1974) and 'reflexivity' is recognised as the attempt to question one's established assumptions and to suspend the 'obvious' while openly listening to alternative ways of framing reality (Gergen, 1999; Macbeth, 2001). In contemporary literature (for example see Sliep \& Gilbert, 2006), this view of reflexivity is often recognised as a space for critical reflection where a researcher can view and question his or her own (and possibly others') decisions and actions. In such a space, a study can be situated in a particular time and space for a contextual interpretation of its conduct. As Roose et al. (2016) point out, by deconstructing their own contexts, a reflexive space enables researchers to see beyond the immediate and mundane and explore the effects of their personal decisions and actions.

The concept of reflexive space has been adopted by researchers from different disciplines such as feminist studies (e.g. Hamilton, 2019), sociology (e.g. Cotter, 2014) and organisational studies (e.g. ledema \& Carroll, 2011). In these studies, researchers use the concept to critically discuss the choices they made during research projects and to make their research practice more transparent. Many of these works (e.g. Boud, 2010; Frost, 2012) are inspired by the work of Hannah Arendt (Arendt, 1999) who theorised critical reflection as an irreducibly plural 'reflexive space', within which, reflection is inevitably shaped by the context in which it occurs.

In the context of social media research, 'reflexive space' serves as a useful concept to explore how methodological difficulties and dilemmas caused by the characteristics of social media shape the way a qualitative study is practiced. It also helps to interrogate the character of knowledge claims the study produces.

\section{A reflexivity framework for social media studies}

\subsection{A reflexive framework}

Figure 1 synthesises the concept of social media as a reflexive space with the three-level view of reflexivity presented in Table 2 . It provides the basis for a holistic and systematic approach to reflexivity in qualitative social media studies. It allows each aspect of a study to be considered separately without undermining its relationships to other areas of the study and without missing the 
bigger picture. Presenting the framework as interconnected methodological layers allows focusing on one aspect without losing sight of the overall research process.

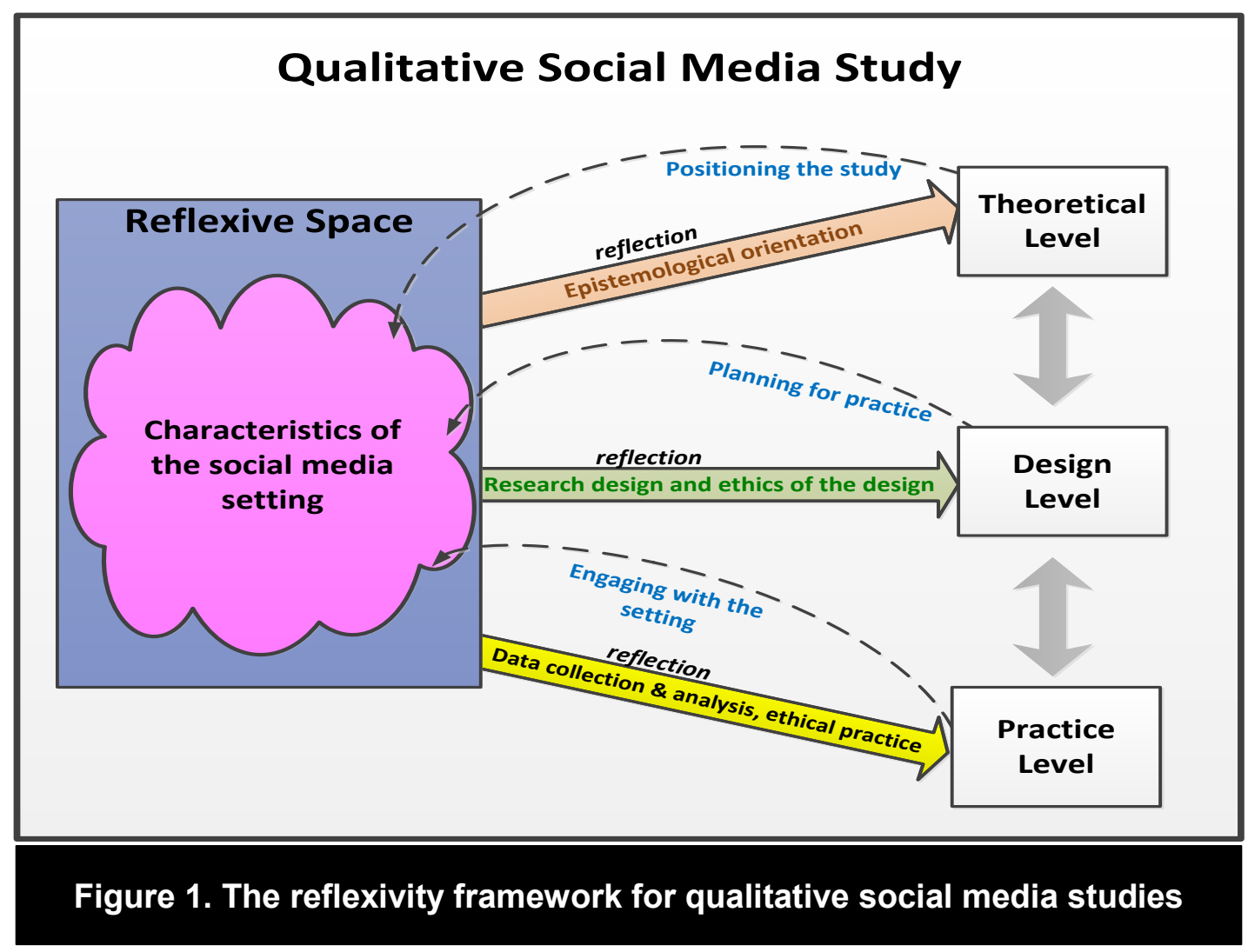

Researchers can use the framework to reflect on how decisions taken in one layer may impact the other layers. As an analytical tool for reflexivity in social media studies, the framework provides a holistic lens through which the research process can be unpacked, assumptions can be questioned, and alternative readings of the role of social media settings can be interrogated and integrated into our understanding of empirical evidence.

Our discussion of reflexivity in social media studies necessitates a conceptualisation of social media itself as a reflexive space. The framework highlights that understanding social media as a reflexive space is central to the practice of reflexivity in qualitative research. The shifting boundaries and virtuality of social media create a space within which information becomes highly intertwined, and the virtuality of the environment does not always afford ways to unpack their ambiguities.

This reflexive space provides opportunities for researchers to reflect on different aspects of the methodological decisions in relation to the nature of the media and the type of data that might exist 
there. In this reflexive space, researchers can reflect upon different issues by asking themselves, for example, to what extent they were able (or not able) to position their participants in their social, political and historical contexts and whether all of these contextual elements are shared in the same way by different social media platforms or participant cohorts. This reflexive space is particularly important when the empirical data is only collected from social media sources, and only limited means exist to corroborate and compare the data.

In our conceptualisation, aspects of this space include but are not restricted to: fluid boundaries (e.g. links between online and offline discussions); co-produced content (e.g. wikis); embedded discourse (e.g. interlinked digital texts); lack of context (e.g. incomplete understanding the of physical or cultural aspects); the ephemeral nature of the data gathered (e.g. posts can disappear of modified); and the difficulty of ascertaining the emotions of the participants (e.g. use of emoticons are not indicatives of real feelings). This leads us to consider social media as an environment where evaluating the relevance of our assumptions and reflecting on our biases are linked to the characteristics and nature of the platform (e.g. Facebook vs Twitter).

\subsection{The practice of reflexivity: some considerations}

By presenting a framework for reflexivity, we have provided an analytical tool which qualitative IS researchers can utilise to consider the implications of their methodological decisions for the quality of their social media studies. In this section, we suggest some considerations for reflexivity that IS researchers might adopt when they use social media as a setting for their research. The considerations we offer here are neither an exhaustive list nor specific to any particular qualitative genre or social media platform. The aim is to demonstrate how researchers can embark on using the framework in their social media studies and put it into practice. The way any of these considerations could be applied to a qualitative study relies considerably on the researcher's creative approach to the adoption of social media sources. We believe IS researchers should exercise their judgement and discretion in deciding whether, how and any of our suggestions could be applied and what questions should be asked in any given qualitative research project. For each guideline, we present a vignette from our own social media study of a patient forum to show how issues related to reflexivity may arise, and how the consideration might be applied. 


\section{\#1 Reflexivity at the theoretical level: Consider the issue of generalisation and abstraction in your social media research}

\section{Vignette 1*: Context and theoretical sampling}

Our last conversation was mostly about the type of claims we can make as the outcome of our analysis. One question was repeatedly raised: How generalisable are our findings? How could we extend our theory using theoretical sampling? We knew that our social media sources had provided us with access to sheer volume of data. Based on our assumptions, that data could selectively be used to fill our theoretical categories.? We noticed that the lack of context in social media demanded extra attention to underlying assumptions and meanings. For us, this meant that it was difficult to interpret and generalise data only with reference to what was happening in social media due to the lack of context. How should we go about the idea of generalisability? We had assumed that characteristics of digital texts had a positive impact on our theoretical sampling. However, in practice we saw that the theoretical sampling process was constrained by the possibility of interactions between researchers and participants in social media settings. This became evident for us that compared to other methods such as interviews or focus groups, researchers can have limited possibilities to direct and control the discussions and that would affect their theoretical sampling and their ability to generalise their findings. However, we were still able to engage with the literature to enhance some of our key theoretical abstractions.

*This vignette is written by the authors based on their recent study of social media in healthcare

At the theoretical level, the focus is on researchers' view toward their research paradigm. The aim of reflexivity at this level is to understand whether working with social media has any implications for a qualitative researchers' epistemological approach. Reflexivity at this level helps researchers to consider and reflect on the extent they can stay faithful to principles of their chosen epistemology and have confidence in the quality of the knowledge obtained from social media sources. As shown earlier, at the theoretical level, researchers can reflect on different aspects of their theoretical position and think about issues that might influence their approach to contextualisation, abstraction, and generalisation of their findings. For example, in social media studies, there is a real opportunity to reflect on how embedded and related sources of data can be abstracted, contextualised, or might corroborate generalisations to theory. Therefore, as shown earlier, this consideration is concerned with reflexivity at the theoretical level.

Recently the role of theory in our discipline has been debated (for instance, see Avison \& Malaurent, 2014; Gregor, 2014; Lee, 2014; Markus, 2014; Weber, 2012). While no consensus has been reached in this debate about the nature of theory, we urge our fellow qualitative researchers not to miss the opportunity to build theory about social media settings. Often qualitative researchers identify themes or concepts but do not proceed to link those concepts to build a substantive theory or build a mechanism or model from them. Flyvbjerg's (2011) advice on theory building using case studies is 
well known, and we suggest that it is entirely appropriate to consider social media settings as cases with flexible boundaries - it is just that we need to be aware of the nature of those boundaries. In the area of social media, the need to theorise is urgent, as we still do not adequately understand the impact of social media on everyday life.

Klein and Myers (1999) point out that generalisation to theory is what distinguishes qualitative research from anecdote. A very real need exists for qualitative researchers to connect their findings critically and reflexively with existing theories, and to be clear about the type of generalisation they are making. As Walsham (1995) suggests, these will be generalisations to theory. Researchers should also consider the influence of culture - as part of the context of their study - in their generalisations (Myers, 1997). Although it is tempting to see some social media contexts as universal, distinct cultures may use social media in vastly different ways. In social media studies, there is also a real opportunity to consider how embedded and related sources of data might corroborate generalisations to theory.

Conducting qualitative research in the realm of social media is, to some extent, uncharted waters. The issues above are but a starting point in developing a cohesive approach to qualitative research in this area. From a practical point of view, this consideration enables researchers to be - as Malaurent and Avison (2017) describe - collaboratively reflexive and make explicit connections between theory and practice. Following Mårtensson and Lee (2004) classification of knowledge (i.e. theoria and praxia), this consideration asks for a reflexive dialogue between academic knowledge that results from social media studies, and the professional expertise possessed by the social media users and practitioners. 


\section{\#2 Reflexivity at the design level: Consider the boundaries of your social media context}

\section{Vignette 2*: Defining boundaries}

It has been over three months that we have been reading and gathering thousands of posts from our patient and carers' forums. The volume of the collected data was enormous, and we were confident that our analysis would result in interesting findings. After all, as qualitative researchers we knew how to treat data and conduct a contextual analysis of qualitative data. However, once we took a step back and looked at our data, we asked one fundamental question: What is the context of data and its boundaries? We realised that the absence of physical and tangible boundaries within and across different platforms made any demarcation between virtual and real very difficult. Also, we realised that due to the virtual nature of the environment, our attempts to trace and access historical data that would help us to create a detailed account of the context and the nature of relations was not very fruitful. This was in contrary to our classical understanding of a research setting since many of interactions in our virtual settings were permeable to the real world. Boundaries, in practice, were informed by features of technology and by participants' and researchers' interpretations of what was real and what was virtual. We also realised that our assumptions about the definition and nature of what is traditionally known as 'unit of analysis' would not fit into what was being observed in social media environments. We found that the best approach was to treat a 'digital object' as the unit of analysis. However, we noticed that characteristics of digital objects in the context of healthcare activities had to be explored and defined in the study.

*This vignette is written by the authors based on their recent study of social media in healthcare

Social media research is a rich arena for reflecting on the boundaries of research projects, and for thinking about how contemporary issues can be studied within those boundaries. Therefore, as discussed in Table 2, this consideration is concerned with reflexivity at the design level of the framework where researchers can reflect on boundaries of what they want to study and where they want to play (Ackerly \& True, 2008; Christians, 2011). Thinking about the boundaries of a research project calls for reflection on the design of the study and thinking of how the design may be influenced by the characteristics of social media sources. At the design level, researchers can, for example, reflect on issues concerned with the identification of the physical and virtual boundaries within which participants could be observed and consider how (complex) concepts might be discussed and experienced by participants differently in a cross-cultural/institutional environment where geographical boundaries cannot be easily demarcated. This is often a difficult task as many of the social interactions in virtual environments permeate to real-world settings.

From a practical perspective, this consideration highlights the need for self-reflexivity (see Avison \& Malaurent, 2014) where a reflexive researcher reflects on his or her own understanding of the nature of the social media context and makes explicit how the assumptions made about its boundaries influenced the process of doing research and how they shape its outcomes. In social media studies, 
research objects are emergent rather than predetermined. This means as Hine (2009) points out, studying social media is only a starting point for considering the boundaries of the projects. Weller (2015) demonstrates that blurring the boundaries in social media studies calls for more visibility regarding how the social, cultural and political boundaries of a study may influence the construction of knowledge and meanings.

This view is, however, a relatively traditional way of looking at the boundaries of research projects. As Kendall (2009) explains, the emergent nature of research objects in social media studies calls for the consideration of project boundaries that are beyond spatial concerns such as physical and virtual locations. In fact, in social media studies, a project's boundaries (of any type), and motivations for determining those boundaries, overlap as researchers are not only motivated and bounded by their theoretical views, but also by ethical and practical issues that inform their decisions of what is or is not possible. Following Hine (2009) and Kendall (2009), we argue that researchers who study virtual settings should consider reflecting, not only on the spatial boundaries of their research project but also on the challenges of identifying the temporal and relational boundaries of their studies. In this context, temporal refers to the time spent and issues of determining the beginning and ending points, while relational refers to the relationships between researchers and the people they study. The blurred boundaries of social media - for instance following links embedded in a blog or post - also allow us to consider opportunities for flexible theoretical sampling (Vaast \& Urquhart 2017), which can be a distinct advantage and increase the robustness of the study. Actively considering the boundaries of the social media study may lead to a more robust design both through spotting opportunities for theoretical sampling and looking for other data sources for corroboration, including offline data sources. 


\title{
\#3 Reflexivity at the practice level: Consider the ethical dimensions of your social media
} research

\author{
Vignette 3*: Privacy dilemma
}

Just left the forum as finished my conversation with Jane about Steve. The news was short and clear. Although I had never met Steve in person and we only were online friends but knowing that he had passed away and was no longer with us made me feel heavy-hearted. Now I needed to think about what I should do with all that data I collected from Steve. I remembered that once he told me that although he had given me a permission to use his data, he was not very sure how private and confidential his data were and because of that he might change his mind at any time. So, what should I do with his data now? I still can access our past conversation on the forum. How should I treat them? In our study of patient forums, often a number of ethical issues would rise, particularly with respect to participants' privacy and confidentiality. By reflecting on those issues, we realised that the ethical considerations in our social media study can have implications for other aspect of the study that we didn't necessarily considered. For example, we noticed that there is a limit for describing our virtual settings. A richer description could compromise the identity of data sources as the separation of participants from their (virtual) settings was nearly impossible. We noted that the whole concept of privacy in virtual environments of social media seemed to be a shifting concept and sometimes privacy expectations were emergent. Participants had different and often inconsistent perceptions about their online privacy, and their expectations could constantly change while they explored different aspects of the forums. In some instances, posts were rendered private after they were published publicly, and they became inaccessible as the producer decided to change the level of access.

*This vignette is written by the authors based on their recent study of social media in healthcare

Principles of ethical research call for measures and actions to protect research participants and researchers against potential harm or distress that may be caused by the research process or its outcomes (Cannella \& Lincoln, 2011). Therefore, as Table 2 suggests, this consideration is more concerned with reflexivity at the practice level. At this level, reflexivity is mostly concerned with the conduct of a qualitative study. At the practice level, the need is to understand the implications of social media sources for ethical data collection, analysis and reporting of a qualitative study (Moreno et al., 2013; Vaast \& Walsham, 2013). Reflexivity at this level aims to provide a clearer understanding of how ethical issues attached to social media sources may influence or challenge the practical aspects of a qualitative study. In social media, data are becoming more malleable, traceable and mineable as the same set of data can exist across multiple platforms at the same time (Buchanan, 2011; Gundecha \& Liu, 2012; Himma \& Tavani, 2008). As such issues such as privacy expectations, accessibility, and confidentiality become central to the ethical considerations of social media research (Eysenbach \& Till, 2001; Flicker, Haans, \& Skinner, 2004; Hine, 2009; Markham, 2008; Vaast \& Walsham, 2013).

In social media research, it is an increasing challenge to make distinctions between what is considered to be a public or a private space (Barnes, 2006; Lange, 2007). Ford (2011) suggests that in the light of 
social media, the difference between public and private is more helpfully theorised as a continuum. As such, depending on who the observer is and the platform being used, in the absence of clear privacy expectations, issues around participant and researcher privacy have to be managed differently. Depending on the participants' perception of what is public and private, the nature of the data, and the ethical guidelines from the researcher's institution, different studies might take very different stances towards privacy. For example, Burkell, Fortier, Wong, and Simpson (2014) found that users had no real expectation of privacy for what they posted online. However, institutional ethics review could insist that privacy concerns still need to be explicitly addressed, for instance, by seeking permissions from group administrators to access the group's posts.

These characteristics have implications for the ethical conduct of qualitative studies. For example, in our qualitative study of patients' forums, we realised that based on the type of forum, participants had different expectations about their identity and privacy. Even the same participants who were members of different forums had different sets of privacy expectations, mostly linked to their perceptions of the features of a platform. Considering the sensitivity of health-related data, the question was whether and how data (posts) collected from different forums could be aggregated without compromising the quality of the evidence as well as the participants' expectations. In another instance, we realised that some of the data we collected from our participants could uniquely identify individuals - if those data were cross-referenced with existing meta-data such as the structure of the forums, search terms used or discussions on particular topics.

We suggest that researchers need to consider the type of social media used in their studies and reflect on their role/s (for example, observer, member or participant) in that space. Researchers also need to reflect on whether the setting they are observing is considered by its members to be a public space or a private one. These considerations can help researchers to think of the risks or potential for harm that might exist for their participants, as well as themselves, when a particular social media platform is exploited for research. It would also help researchers gain a better understanding of the nature of their interaction with their participants and the sensitivity of the collected data. In addition, special consideration must be given to issues such as understanding participants' privacy expectations, designing methods for obtaining informed consent, and how (and whether) the anonymity and the confidentiality of participants' identities can be maintained, directly or indirectly, once the data is collected. 


\section{\#4 Integrated multi-level reflexivity: Consider how your social media data sources}

\section{influence contextualisation}

\section{Vignette 4*: Looking for the storyline}

During the analysis of our social media data we realised that it was difficult to position our participants in their social and historical context. The virtuality of settings, lack of access to sensory data, amorphous and fluid boundaries, and a high level of intricacy of the data didn't allow us to confidently claim such contextualisation. As a result, we found it difficult to interpret our data only in reference to what was happening in social media. On the bright side, however, we were able to access to detailed data about a topic through social media and it was possible to identify the central texts and conduct an analysis around them. However, the lack of context demanded extra attention to be paid to underlying assumptions and meanings. One of the assumptions that we had to revisit was about the definition and nature of what is traditionally known as 'research setting'. We realised the established understanding of 'research setting' would not fit into what was being observed in social media environments. Nonetheless, the biggest challenge was to clearly understand the narrative of collected data and form a clear storyline for the whole data set, as there was lots of irrelevant and convoluted information.

*This vignette is written by the authors based on their recent study of social media in healthcare

Reflexivity should be treated as a holistic and interconnected concept that integrates the theoretical, design, and practice levels. This entails not only thinking about each level separately but also considering implications of reflection at each level for other levels. As shown earlier, the contextualisation consideration highlights the need to not only reflect on the design of a study and thinking of how the context of social media platform (e.g. culture) might affect the design of the study, but also calls for the necessity of reflecting on the extent that the practice of collecting and analysing data can represent the contextual aspect of the study. It also highlights the need for reflecting on how the extent of contextualisation of social media data may influence the generalisability of the findings (Davison \& Martinsons, 2016).

As a principle of qualitative research, contextualisation is a necessary element of a qualitative study (Denzin \& Lincoln, 2011). When the study is reported, the intended audience should be able to see the chain of evidence and how the current situation under investigation has emerged (Richardson \& Adams St. Pierre, 2018). However, as demonstrated in Table 1, in Section 2, the issue of contextualisation is one of the key areas of challenge in qualitative social media research and can be seen as an issue for reflexivity at the theoretical, design and practice levels of the framework.

For most social media platforms, the boundaries are constantly shifting, and it is difficult (if not impossible) to locate any perceptual, or even conceptual, demarcations between domains of activities, events and interactions. In other words, it is difficult to identify the boundaries of the 
context of a study and make distinctions between the starting and ending points of events and interactions. As such, researchers should reflect on the challenging aspects of contextualisation in social media studies. In traditional qualitative research, contextualisation is achieved by creating a rich description of the case. In social media research, we would contend that there is still the opportunity to use rich descriptions, despite the evident difficulties of understanding the immediate context. For instance, a case study of a Twitter feed during a terrorist event could take care to describe that event, and subsequent outcomes, as a way of historically framing the case study and enabling the reader to understand and interpret those tweets as a product of that particular time.

As the practice of reflexivity, this consideration highlights the need for both self-reflexivity and domain reflexivity (Avison \& Malaurent, 2014) where reflexive researchers reflect on their data sources and how the collected data are understood and interpreted during the course of a study. The shifting boundaries create a space so that sometimes (if not most of the time) messages and threads (data) become highly intertwined, and the virtuality of the environment does not always afford ways to unpack their ambiguities. Researchers might consider reflecting on such issues by, for example, asking themselves to what extent they were able (or not able) to position their participants in their social, political and historical contexts and whether all of these contextual elements are shared in the same way by different participant cohorts. Researchers could also reflect on the nature of the data that comes from social media that may (or may not) lead to their understanding of the context of their study. These considerations are particularly important when the empirical data is only collected from social media sources, and only limited means exist to corroborate and compare the data. At the practice level, the transient nature of social media can also challenge the traditional understanding of what is known as a 'research setting' and how to collect data therein. Obviously, researchers can take practical measures to deal with transience, such as making sure they keep records of the data rather than relying on any permanence of data in a social media setting. Researchers should consider how their understandings of a research setting and its boundaries may have been formed or may have influenced their approach to collecting what is considered social media empirical data. In our study of patient forums, the virtuality and transient nature of the setting gave rise to many questions about how we could gather historical and sensory data that would help us interpret events and interactions in social media environments clearly and more accurately. 


\section{Discussion and conclusion}

Studies show that social media technologies can permeate and alter interactions and their possible outcomes at the dyadic, group and cultural levels (Markham, 2008). We contend that social media is unique in the ways these technologies can influence and shape researchers' perceptions of social reality and configure their interactions with their participants. These influences have the potential to shift the nature of sensemaking at the theoretical, design and practice levels of a study in which qualitative researchers collect, make sense of and represent data.

By privileging certain features of interaction (Halpern \& Gibbs, 2013; Majchrzak, Faraj, Kane, \& Azad, 2013; Treem \& Leonardi, 2012), and at the same time obscuring others (Antheunis, Tates, \& Nieboer, 2013; Correa, Hinsley, \& De Zuniga, 2010) social media confounds traditional methods of capturing and conceptualising social relationships of all kinds. The traditional challenge of understanding social reality in context has become even more complicated by the blurred boundaries between researchers and participants and by the increasing power of researchers in representing their participants (Christians, 2011). These issues challenge qualitative IS researchers to re-examine traditional assumptions and previously taken-for-granted rubrics of qualitative research in the IS domain and reflect on how the practice of qualitative study can be affected when we shift our focus from traditional research settings to social media settings.

Such methodological challenges and reflection around social media studies are not confined to our own discipline. Scholars from many other disciplines such as sociology and cultural studies (Lysloff, 2003), psychology (Mileham, 2007), communication and media (Treem \& Leonardi, 2012) and education (Leander \& McKim, 2003) have also found unique research opportunities and challenges in social media environments. In these disciplines, scholars have enriched the landscape of their qualitative studies either by introducing new and innovative methods of studying online life, or by reflecting on their practices and highlighting some of the methodological challenges of using social media sources. For instance, Markham (2008) treats reflexivity as a fundamental aspect of studying social media and online communities and highlights five areas on which qualitative researchers need to reflect when they study virtual online communities: (1) how boundaries are defined; (2) what constitutes data; (3) how people can be understood through the text; (4) the interpretation of the text with limited context; and (5) the ethics of representation. 
For Gatson (2011), any study of online communities and social media is, in fact, an 'online autoethnography' in which the researcher is at the heart of the reflexivity. According to Gatson (2011), when studying online communities, qualitative researchers should be prepared to think and reflect on their decisions regarding how to reference online places and experiences, and how their research can be ethical and without deception.

Reflexivity is intertwined with the study of online life and social media across different disciplines. Our goal in presenting our framework is to make visible both this relationship and the ways reflexivity can be used. We believe our framework can help IS researchers to be vigilant about the use of social media in IS research practices and is consistent with Malaurent and Avison (2017) call for more transparency in our reflexive approaches.

We also believe that the comparatively low level of discussion in IS on the challenges of social media research has been a missed opportunity for IS qualitative researchers to engage in constructive debates and progressive discussions around our methodological decisions. The framework we have presented in this paper enables qualitative researchers to examine and discuss the role of reflexivity as a methodological principle and it provides a methodological link between qualitative research in IS, and the wider community of qualitative researchers in other disciplines.

In comparison to how reflexivity in social media research is discussed in other disciplines, our framework and considerations exhibit some unique features. First, the framework offers a holistic perspective toward reflexivity, presenting a structured and systematic approach to relevant issues. This is an important feature, as it enables researchers to systematically unpack their methodological approaches, and critically question their methodological decisions while maintaining the bigger picture of their studies. Second, the framework is flexible. While not prescriptive, it does suggest a number of areas and questions that should be considered for reflection. Researchers can regard the considerations as starting points for their reflections, and tailor them according to the specific characteristics of their social media studies. We believe that these features make the framework a good and practical conceptual artefact for understanding and communicating the complexity of studying virtual settings (Alter, 2017).

We developed our framework with one major question in mind: What are the implications of reflexivity for qualitative social media research? In answer, we respond that reflexivity equips 
researchers with powerful analytical apparatuses to identify, understand and make visible the complex relationship between the researcher and the research process.

By presenting a framework for reflexivity, we hope that we have provided an analytical tool with which qualitative IS researchers can rethink the implications of their methodological decisions for the quality of their social media studies, and navigate the somewhat choppy waters of social media research. The suggestions we offer here are neither an exhaustive list nor specific to any particular qualitative genre or social media platform. The way any of these recommendations could be applied to a qualitative study relies considerably on the researcher's creative approach to the adoption of social media sources. Applying this framework to one of our own studies resulted in several critical insights, the most compelling being that in studying social media, we are dealing with sources that have previously unexplored affordances. For instance, at the theoretical level, it enabled us to reflect on the boundary of a social media study, and how we can place the study and sources in a broader social and historical context. At the practical level, we realised that that participant expectation of privacy could be conceptualised in different ways.

Identifying, acknowledging and attempting to address these kinds of gaps and issues in our study helped us to gain more confidence in our empirical findings, and consequently put forward stronger and more compelling arguments. It is our hope that our fellow IS researchers will find the framework useful in the same way. Even though our framework and guidelines focus on social media, we suggest that our arguments are applicable to other forms of virtual settings. We look forward to engaging with our fellow researchers in future discussions of the methodological challenges of social media studies and offer this paper as the first step in that direction.

\section{References}




\section{Appendix 1 - Overview of Qualitative Studies Published in Top IS Journals that Use Social Media as Sources of Empirical Data (2005-2020)}

\begin{tabular}{|c|c|c|c|c|c|c|c|c|c|c|c|}
\hline$\stackrel{\varrho}{\stackrel{\Xi}{*}}$ & $\begin{array}{l}\bar{n} \\
\frac{n}{0} \\
\frac{c}{5} \\
\frac{3}{4}\end{array}$ & $\stackrel{\bar{\varpi}}{\nu}$ & $\begin{array}{l}\overline{\text { OO}} \\
\stackrel{5}{5} \\
\text { 음 }\end{array}$ & 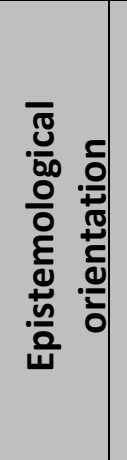 & 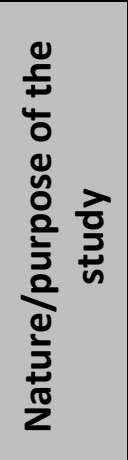 & 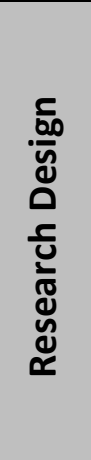 & 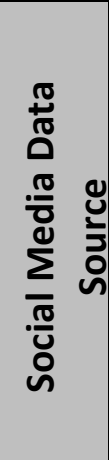 & 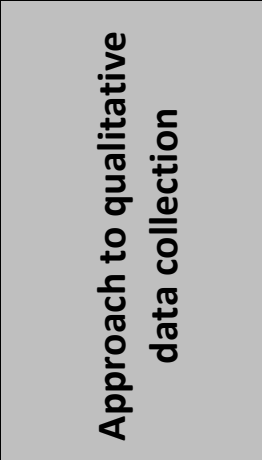 & 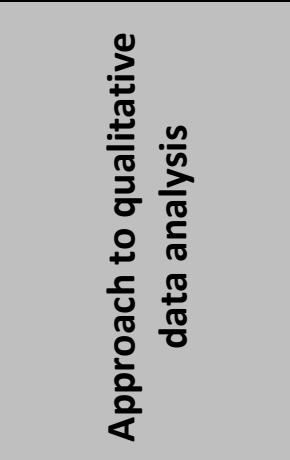 & 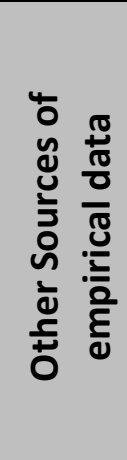 & 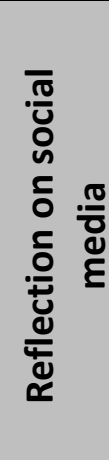 \\
\hline $\begin{array}{l}\text { Social ties, knowledge } \\
\text { sharing and successful } \\
\text { collaboration in } \\
\text { globally distributed } \\
\text { system development } \\
\text { projects }\end{array}$ & $\begin{array}{l}\text { Kotlarsky \& } \\
\text { Oshri }\end{array}$ & 苂 & $\begin{array}{l}\text { European } \\
\text { Journal of } \\
\text { Informatio } \\
\text { n Systems }\end{array}$ & 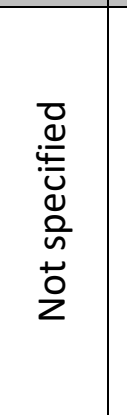 & 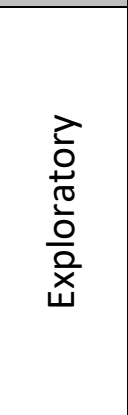 & $\begin{array}{l}\frac{.0}{E} \\
\frac{0}{0} \\
\frac{0}{00} \\
0 \\
0 \\
\frac{c}{ \pm} \\
\pm\end{array}$ & $\begin{array}{l}\frac{0}{2} \\
\frac{10}{3} \\
\frac{0}{7} \\
0 \\
\frac{0}{0}\end{array}$ & $\begin{array}{c}\text { Mass } \\
\text { collection of } \\
\text { qualitative } \\
\text { and } \\
\text { quantitative } \\
\text { data } \\
\text { informed by a } \\
\text { theory }\end{array}$ & $\begin{array}{l}\text { Hermeneutic } \\
\text { approach to } \\
\text { qualitative (no } \\
\text { further details } \\
\text { provided) }\end{array}$ & 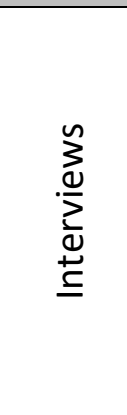 & 을 \\
\hline $\begin{array}{l}\text { Exploring the dynamics } \\
\text { of blog communities: } \\
\text { the case of MetaFilter }\end{array}$ & $\begin{array}{l}\text { Silva, Goel \& } \\
\text { Mousavidin }\end{array}$ & 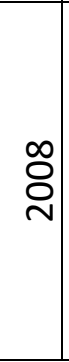 & $\begin{array}{l}\text { Informatio } \\
\text { n Systems } \\
\text { Journal }\end{array}$ & 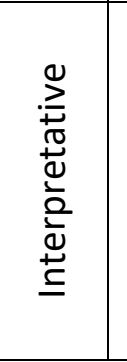 & $\begin{array}{l}\frac{7}{0} \\
\frac{0}{\pi} \\
\frac{0}{0} \\
\frac{0}{x} \\
\text { ய }\end{array}$ & 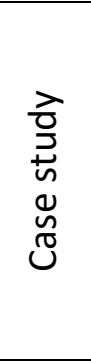 & 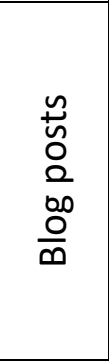 & $\begin{array}{l}\text { Stratified } \\
\text { sampling } \\
\text { approach } \\
\text { within each } \\
\text { theoretical } \\
\text { category }\end{array}$ & $\begin{array}{l}\text { Hermeneutic } \\
\text { approach to } \\
\text { inductive } \\
\text { qualitative } \\
\text { coding and the } \\
\text { interpretation } \\
\text { of text }\end{array}$ & 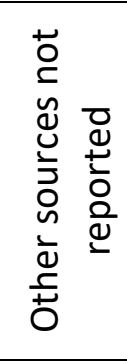 & 은 \\
\hline
\end{tabular}




\begin{tabular}{|c|c|c|c|c|c|c|c|c|c|c|c|}
\hline $\begin{array}{l}\text { Enacting language } \\
\text { games: the } \\
\text { development of a sense } \\
\text { of 'we-ness' in online } \\
\text { forums }\end{array}$ & $\begin{array}{l}\text { Fayard \& } \\
\text { DeSancti }\end{array}$ & ஓे. & $\begin{array}{l}\text { Informatio } \\
\text { n Systems } \\
\text { Journal }\end{array}$ & 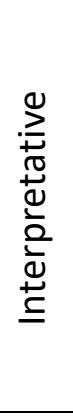 & $\begin{array}{l}\frac{\pi}{0} \\
\frac{0}{\pi} \\
\frac{0}{2} \\
\frac{0}{x}\end{array}$ & 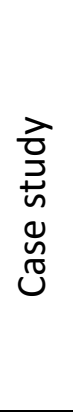 & 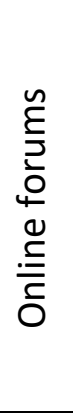 & $\begin{array}{l}\text { Theoretical } \\
\text { sampling } \\
\text { informed by } \\
\text { the grounded } \\
\text { theory }\end{array}$ & $\begin{array}{c}\text { Qualitative } \\
\text { analysis of } \\
\text { discourses } \\
\text { between online } \\
\text { forums } \\
\text { Hermeneutic } \\
\text { approach - } \\
\text { inductive coding }\end{array}$ & 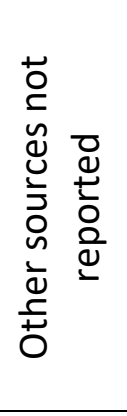 & $\frac{0}{2}$ \\
\hline $\begin{array}{l}\text { Enacting language } \\
\text { games: the } \\
\text { development of a sense } \\
\text { of 'we-ness' in online } \\
\text { forums }\end{array}$ & $\begin{array}{l}\text { Fayard \& } \\
\text { DeSanctis }\end{array}$ & 염 & $\begin{array}{l}\text { Informatio } \\
\text { n Systems } \\
\text { Journal }\end{array}$ & 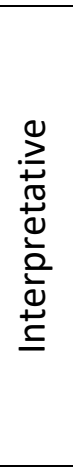 & $\begin{array}{l}\frac{2}{0} \\
\frac{0}{\pi} \\
\frac{0}{0} \\
\frac{2}{x}\end{array}$ & 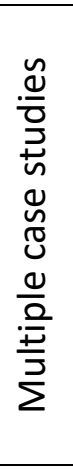 & 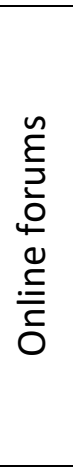 & $\begin{array}{l}\text { Iteratively } \\
\text { data } \\
\text { collection the } \\
\text { refinement of } \\
\text { theoretical } \\
\text { categories }\end{array}$ & $\begin{array}{l}\text { Hermeneutic } \\
\text { approach to } \\
\text { iterative } \\
\text { analysis of } \\
\text { discourse in two } \\
\text { online forums, } \\
\text { informed by a } \\
\text { theoretical } \\
\text { framework }\end{array}$ & 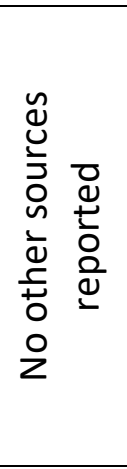 & ${ }^{2}$ \\
\hline $\begin{array}{l}\text { Exploring temporal } \\
\text { coordination of events } \\
\text { with Facebook.com }\end{array}$ & $\begin{array}{l}\text { Khan } \\
\text { \& Jarvenpaa }\end{array}$ & 召 & $\begin{array}{l}\text { Journal of } \\
\text { Informatio } \\
n \\
\text { Technolog } \\
y\end{array}$ & 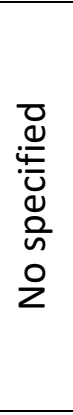 & $\begin{array}{l}\frac{0}{0} \\
\frac{0}{0} \\
\frac{0}{x} \\
\frac{x}{4}\end{array}$ & 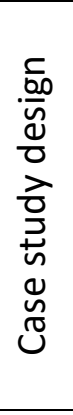 & 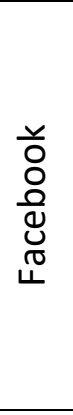 & $\begin{array}{c}\text { Mass } \\
\text { collection of } \\
\text { qualitative } \\
\text { and } \\
\text { quantitative } \\
\text { data } \\
\text { informed by a } \\
\text { theory }\end{array}$ & $\begin{array}{l}\text { Hermeneutic } \\
\text { approach to } \\
\text { qualitative (no } \\
\text { further details } \\
\text { provided), } \\
\text { complemented } \\
\text { with statistical } \\
\text { analysis }\end{array}$ & 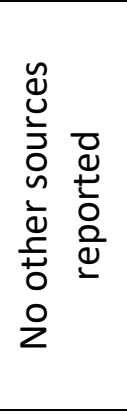 & io \\
\hline
\end{tabular}




\begin{tabular}{|c|c|c|c|c|c|c|c|c|c|c|c|}
\hline $\begin{array}{l}\text { Conviviality of Internet } \\
\text { social networks: An } \\
\text { exploratory study of } \\
\text { Internet campaigns in } \\
\text { Iran }\end{array}$ & $\begin{array}{l}\text { Ameripour, } \\
\text { Nicholson \& } \\
\text { Newman }\end{array}$ & 吕 & $\begin{array}{l}\text { Journal of } \\
\text { Informatio } \\
n \\
\text { Technolog } \\
y\end{array}$ & 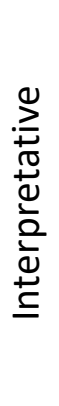 & $\begin{array}{l}\frac{2}{0} \\
+\frac{0}{0} \\
\frac{0}{0} \\
\frac{0}{x}\end{array}$ & 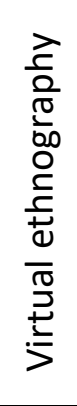 & 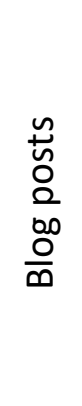 & $\begin{array}{c}\text { Mass } \\
\text { collection of } \\
\text { qualitative } \\
\text { data followed } \\
\text { by theoretical } \\
\text { sampling } \\
\text { informed by a } \\
\text { theory }\end{array}$ & $\begin{array}{l}\text { Qualitative } \\
\text { inductive coding } \\
\text { (no further } \\
\text { details } \\
\text { provided) }\end{array}$ & 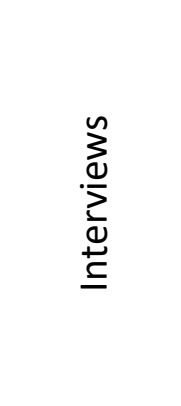 & 2 \\
\hline $\begin{array}{l}\text { Using a grounded } \\
\text { theory approach to } \\
\text { study online } \\
\text { collaboration } \\
\text { behaviours }\end{array}$ & $\begin{array}{l}\text { Gasson \& } \\
\text { Waters }\end{array}$ & $\stackrel{m}{\stackrel{m}{0}}$ & $\begin{array}{l}\text { European } \\
\text { Journal of } \\
\text { Informatio } \\
\text { n Systems }\end{array}$ & 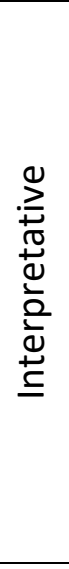 & $\begin{array}{l}\frac{2}{0} \\
\frac{\pi}{0} \\
\frac{0}{0} \\
\frac{0}{x}\end{array}$ & 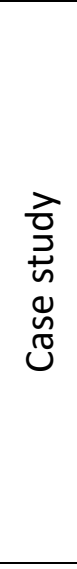 & 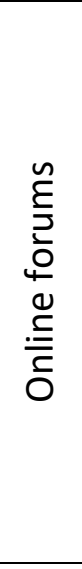 & $\begin{array}{l}\text { As per the } \\
\text { grounded } \\
\text { theory, the } \\
\text { collection of } \\
\text { qualitative } \\
\text { data } \\
\text { continued } \\
\text { until } \\
\text { theoretical } \\
\text { saturations } \\
\text { are reached }\end{array}$ & $\begin{array}{l}\text { Three stage of } \\
\text { open, selective, } \\
\text { and theoretical } \\
\text { and inductive } \\
\text { coding }\end{array}$ & 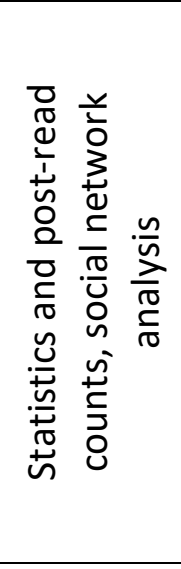 & $\frac{0}{2}$ \\
\hline $\begin{array}{l}\text { Member engagement } \\
\text { within digitally enabled } \\
\text { social network } \\
\text { communities: new } \\
\text { methodological } \\
\text { considerations }\end{array}$ & $\begin{array}{l}\text { Germonprez } \\
\text { \& Hovorka }\end{array}$ & $\stackrel{m}{\stackrel{m}{0}}$ & $\begin{array}{l}\text { Informatio } \\
\text { n Systems } \\
\text { Journal }\end{array}$ & 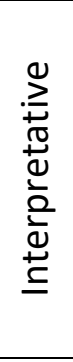 & 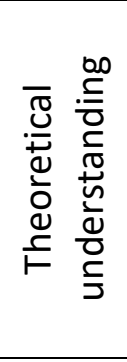 & 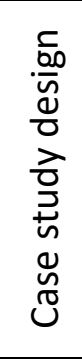 & 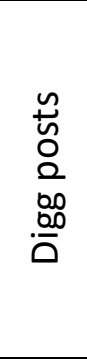 & $\begin{array}{l}\text { Collection of } \\
\text { qualitative } \\
\text { data from } \\
\text { social media } \\
\text { informed by a } \\
\text { theoretical } \\
\text { framework }\end{array}$ & $\begin{array}{c}\text { Qualitative } \\
\text { analysis (no } \\
\text { further details } \\
\text { provided), } \\
\text { complemented } \\
\text { with statistical } \\
\text { analysis }\end{array}$ & 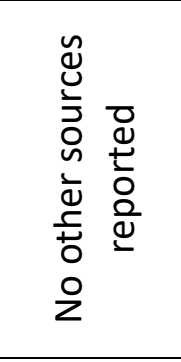 & $\stackrel{\mathscr{\varpi}}{\searrow}$ \\
\hline
\end{tabular}




\begin{tabular}{|c|c|c|c|c|c|c|c|c|c|c|c|}
\hline $\begin{array}{l}\text { Blogging for ICT4D: } \\
\text { reflecting and engaging } \\
\text { with peers to build } \\
\text { development discourse }\end{array}$ & $\begin{array}{l}\text { Ferguson, } \\
\text { Soekijad, } \\
\text { Huysman, \& } \\
\text { Vaast }\end{array}$ & $\stackrel{m}{\stackrel{m}{0}}$ & $\begin{array}{l}\text { Informatio } \\
\text { n Systems } \\
\text { Journal }\end{array}$ & 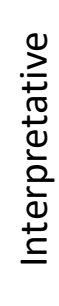 & $\begin{array}{l}\frac{7}{0} \\
\frac{0}{0} \\
\frac{\pi}{0} \\
\frac{0}{2} \\
\frac{x}{4}\end{array}$ & 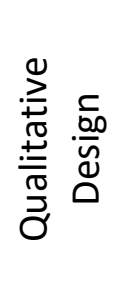 & $\begin{array}{l}\stackrel{n}{\sharp 口} \\
\check{O} \\
\frac{0}{00} \\
\frac{0}{n}\end{array}$ & $\begin{array}{l}\text { Theoretical } \\
\text { sampling } \\
\text { inspired by } \\
\text { the grounded } \\
\text { theory }\end{array}$ & $\begin{array}{c}\text { Qualitative } \\
\text { analysis and } \\
\text { inductive coding } \\
\text { inspired by the } \\
\text { grounded } \\
\text { theory }\end{array}$ & 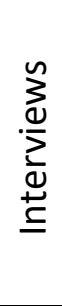 & 운 \\
\hline $\begin{array}{l}\text { Talking about } \\
\text { technology: the } \\
\text { emergence of a new } \\
\text { actor category through } \\
\text { new media }\end{array}$ & $\begin{array}{l}\text { Vaast, } \\
\text { Davidson \& } \\
\text { Mattson }\end{array}$ & $\stackrel{m}{\stackrel{D}{0}}$ & $\begin{array}{l}\text { MIS } \\
\text { Quarterly }\end{array}$ & 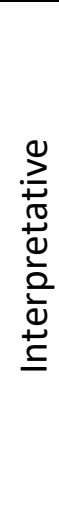 & 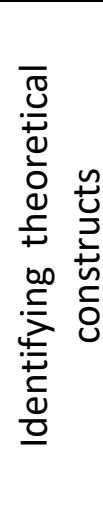 & 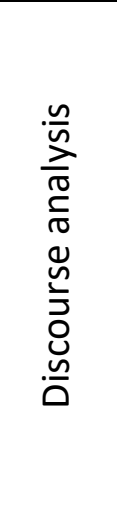 & $\begin{array}{l}\tilde{n} \\
\tilde{n} \\
0 \\
\frac{0}{00} \\
\frac{0}{\infty}\end{array}$ & $\begin{array}{l}\text { Collection of } \\
\text { qualitative } \\
\text { data over } \\
\text { three years } \\
\text { including } \\
\text { theoretical } \\
\text { sampling } \\
\text { informed } \\
\text { emerged } \\
\text { categories }\end{array}$ & $\begin{array}{l}\text { Iteratively } \\
\text { coding for the } \\
\text { refinement of } \\
\text { theoretical } \\
\text { categories }\end{array}$ & 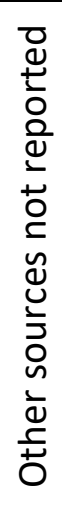 & 은 \\
\hline $\begin{array}{l}\text { Performing embodied } \\
\text { identity in virtual } \\
\text { worlds }\end{array}$ & Schultze & $\stackrel{+}{\vec{D}}$ & $\begin{array}{l}\text { European } \\
\text { Journal of } \\
\text { Informatio } \\
\text { n Systems }\end{array}$ & 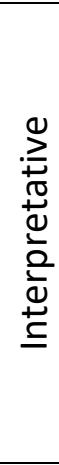 & $\begin{array}{l}\frac{2}{0} \\
\frac{0}{0} \\
\frac{0}{0} \\
\frac{0}{2} \\
\frac{1}{4}\end{array}$ & 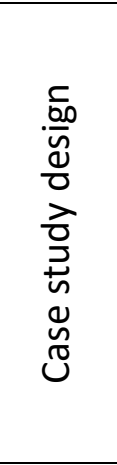 & 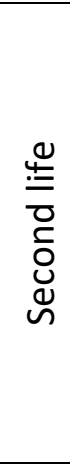 & $\begin{array}{l}\text { Iteratively } \\
\text { data } \\
\text { collection the } \\
\text { refinement of } \\
\text { theoretical } \\
\text { categories }\end{array}$ & $\begin{array}{l}\text { Inductive coding } \\
\text { Informed by the } \\
\text { grounded } \\
\text { theory to } \\
\text { explore the } \\
\text { dimensions of } \\
\text { existing } \\
\text { theoretical } \\
\text { categories }\end{array}$ & $\begin{array}{l}\mathscr{y} \\
\frac{\mathscr{T}}{L} \\
\frac{\pi}{0} \\
0 \\
0 \\
\frac{0}{0} \\
\frac{c}{2}\end{array}$ & 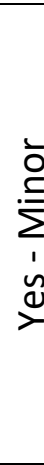 \\
\hline
\end{tabular}




\begin{tabular}{|c|c|c|c|c|c|c|c|c|c|c|c|}
\hline $\begin{array}{l}\text { The deep structure of } \\
\text { organizational online } \\
\text { networking - an actor- } \\
\text { oriented case study }\end{array}$ & $\begin{array}{l}\text { Trier \& } \\
\text { Richter }\end{array}$ & $\underset{\sim}{\stackrel{\sim}{\sim}}$ & $\begin{array}{l}\text { Informatio } \\
\text { n Systems } \\
\text { Journal }\end{array}$ & 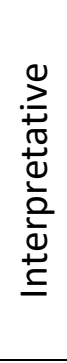 & $\begin{array}{l}\frac{1}{0} \\
\frac{0}{\pi} \\
\frac{0}{0} \\
\frac{0}{2} \\
\frac{x}{x}\end{array}$ & 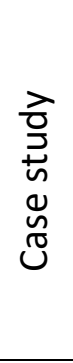 & 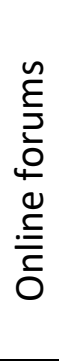 & $\begin{array}{l}\text { Theoretical } \\
\text { sampling and } \\
\text { corroboration }\end{array}$ & $\begin{array}{c}\text { Hermeneutic } \\
\text { approach to } \\
\text { iterative } \\
\text { qualitative } \\
\text { coding informed } \\
\text { by a theoretical } \\
\text { framework }\end{array}$ & 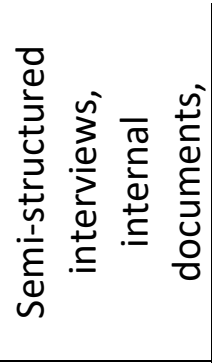 & 우 \\
\hline $\begin{array}{l}\text { Patient Data as Medical } \\
\text { Facts: Social Media } \\
\text { Practices as a } \\
\text { Foundation for Medical } \\
\text { Knowledge Creation. }\end{array}$ & $\begin{array}{l}\text { Kallinikos \& } \\
\text { Tempini }\end{array}$ & 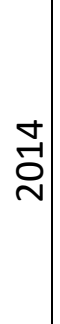 & $\begin{array}{l}\text { Informatio } \\
\text { n Systems } \\
\text { Research }\end{array}$ & 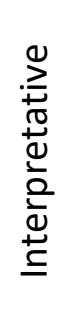 & $\begin{array}{l}\frac{1}{0} \\
+\frac{0}{0} \\
\frac{0}{0} \\
\frac{0}{2} \\
\frac{x}{4}\end{array}$ & 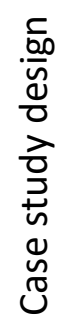 & 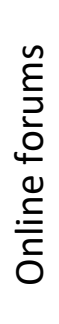 & $\begin{array}{l}\text { Theoretical } \\
\text { sampling } \\
\text { informed by } \\
\text { the grounded } \\
\text { theory }\end{array}$ & $\begin{array}{c}\text { Iterative } \\
\text { analysis of } \\
\text { qualitative data } \\
\text { and constant } \\
\text { comparison } \\
\text { with literature }\end{array}$ & $\begin{array}{l}\sum_{0}^{n} \\
\stackrel{0}{2} \\
\stackrel{ \pm}{ \pm} \\
\underline{\Xi}\end{array}$ & 운 \\
\hline $\begin{array}{l}\text { Entanglements in } \\
\text { practice: performing } \\
\text { anonymity through } \\
\text { social media }\end{array}$ & $\begin{array}{l}\text { Scott \& } \\
\text { Orlikowski }\end{array}$ & $\underset{\sim}{\stackrel{\sim}{~}}$ & $\begin{array}{l}\text { MIS } \\
\text { Quarterly }\end{array}$ & 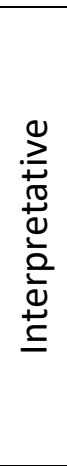 & $\begin{array}{l}\frac{2}{0} \\
\frac{0}{\pi} \\
\frac{0}{0} \\
\frac{0}{2} \\
\frac{x}{x}\end{array}$ & 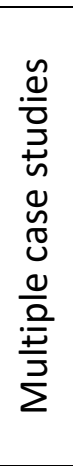 & $\begin{array}{l}\stackrel{n}{4} \\
\check{0} \\
\frac{0}{00} \\
\frac{0}{\infty}\end{array}$ & $\begin{array}{l}\text { Collection of } \\
\text { qualitative } \\
\text { data over two } \\
\text { year from } \\
\text { multiple } \\
\text { sources }\end{array}$ & $\begin{array}{l}\text { Informed by the } \\
\text { grounded } \\
\text { theory, } \\
\text { inductive and } \\
\text { iterative } \\
\text { approach } \\
\text { involving several } \\
\text { rounds of } \\
\text { coding }\end{array}$ & 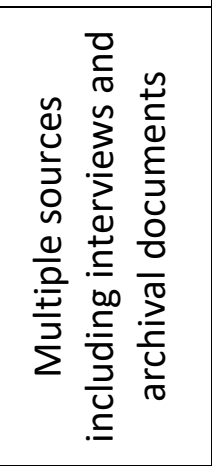 & 운 \\
\hline
\end{tabular}




\begin{tabular}{|c|c|c|c|c|c|c|c|c|c|c|c|}
\hline $\begin{array}{l}\text { A design theory for } \\
\text { digital platforms } \\
\text { supporting online } \\
\text { communities: a multiple } \\
\text { case study }\end{array}$ & $\begin{array}{l}\text { Spagnoletti, } \\
\text { Resca \& Lee }\end{array}$ & 昜 & $\begin{array}{l}\text { Journal of } \\
\text { Informatio } \\
n \\
\text { Technolog } \\
y\end{array}$ & 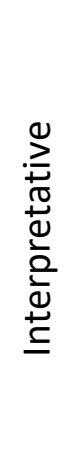 & 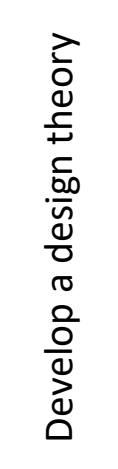 & 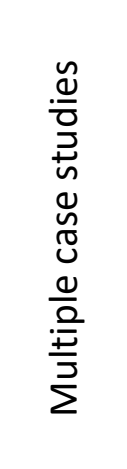 & 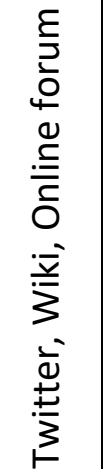 & $\begin{array}{l}\text { Iteratively } \\
\text { data } \\
\text { collection the } \\
\text { refinement of } \\
\text { theoretical } \\
\text { categories }\end{array}$ & $\begin{array}{c}\text { Iterative } \\
\text { analysis of } \\
\text { qualitative data } \\
\text { informed by a } \\
\text { theoretical } \\
\text { framework }\end{array}$ & : & $\stackrel{\circ}{z}$ \\
\hline $\begin{array}{l}\text { Communicational } \\
\text { ambidexterity as a new } \\
\text { capability to manage } \\
\text { social media } \\
\text { communication within } \\
\text { organizations }\end{array}$ & $\begin{array}{l}\text { Huanga, } \\
\text { Baptistaa, \& } \\
\text { Newell }\end{array}$ & $\stackrel{\sim}{0}$ & $\begin{array}{l}\text { Journal of } \\
\text { Strategic } \\
\text { Informatio } \\
\text { n Systems }\end{array}$ & 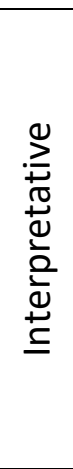 & $\begin{array}{l}\frac{7}{0} \\
+\frac{0}{0} \\
\frac{0}{0} \\
\frac{0}{x}\end{array}$ & 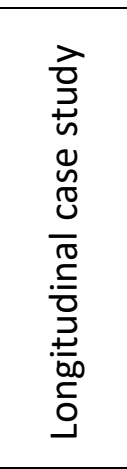 & 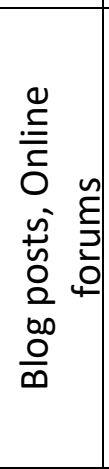 & $\begin{array}{c}\text { Multiple } \\
\text { phases of } \\
\text { data } \\
\text { collection } \\
\text { informed by a } \\
\text { theoretical } \\
\text { framework } \\
\text { and emerged } \\
\text { concepts }\end{array}$ & $\begin{array}{c}\text { Iterative } \\
\text { analysis of } \\
\text { qualitative data } \\
\text { and constant } \\
\text { comparison } \\
\text { with literature }\end{array}$ & 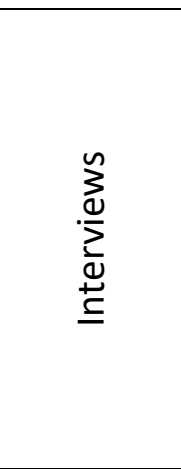 & $\stackrel{\circ}{z}$ \\
\hline $\begin{array}{l}\text { Design for social media } \\
\text { engagement: Insights } \\
\text { from elderly care } \\
\text { assistance }\end{array}$ & $\begin{array}{l}\text { Spagnolettia, } \\
\text { Rescab, \& } \\
\text { Sæb } \varnothing\end{array}$ & $\stackrel{n}{\stackrel{n}{N}}$ & $\begin{array}{l}\text { Journal of } \\
\text { Strategic } \\
\text { Informatio } \\
\text { n Systems }\end{array}$ & 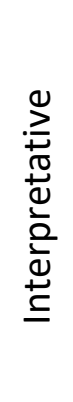 & 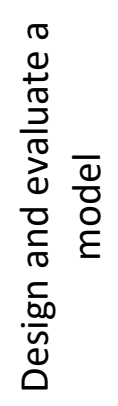 & 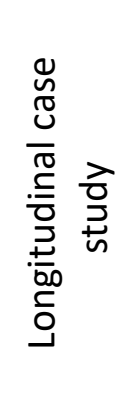 & 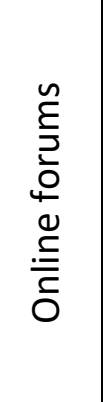 & $\begin{array}{l}\text { Multiple } \\
\text { phases of } \\
\text { data } \\
\text { collection } \\
\text { informed by a } \\
\text { theoretical } \\
\text { framework }\end{array}$ & $\begin{array}{c}\text { Iterative } \\
\text { analysis of } \\
\text { qualitative data }\end{array}$ & 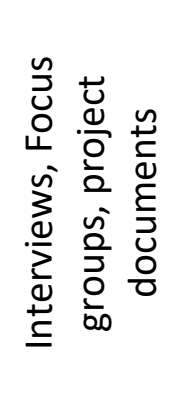 & 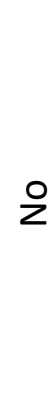 \\
\hline
\end{tabular}




\begin{tabular}{|c|c|c|c|c|c|c|c|c|c|c|c|}
\hline $\begin{array}{l}\text { ICT-Enabled Community } \\
\text { Empowerment in Crisis } \\
\text { Response: Social Media } \\
\text { in Thailand Flooding } \\
2011\end{array}$ & $\begin{array}{l}\text { Ling ,Pan, } \\
\text { Ractham, \& } \\
\text { Kaewkitipon } \\
\text { g }\end{array}$ & $\stackrel{n}{0}$ & $\begin{array}{l}\text { Journal of } \\
\text { the } \\
\text { Associatio } \\
\mathrm{n} \text { for } \\
\text { Informatio } \\
\mathrm{n} \text { Systems }\end{array}$ & 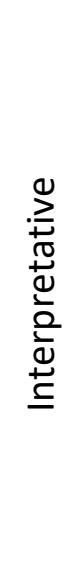 & $\begin{array}{l}\frac{7}{0} \\
\frac{0}{0} \\
\frac{0}{0} \\
\frac{0}{2} \\
\ddot{w}\end{array}$ & 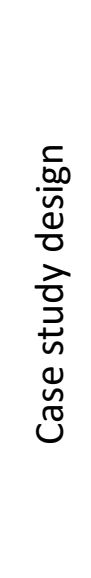 & 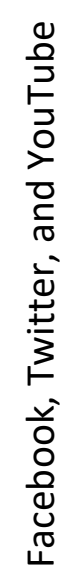 & $\begin{array}{l}\text { Multiple } \\
\text { phases of } \\
\text { data } \\
\text { collection } \\
\text { informed by a } \\
\text { theoretical } \\
\text { framework }\end{array}$ & $\begin{array}{c}\text { Iterative } \\
\text { analysis of } \\
\text { qualitative data } \\
\text { and constant } \\
\text { comparison } \\
\text { with literature }\end{array}$ & 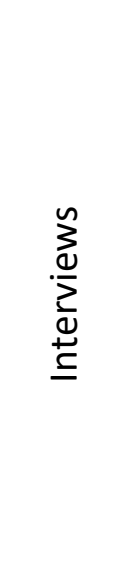 & $\stackrel{0}{2}$ \\
\hline $\begin{array}{l}\text { Distributed tuning of } \\
\text { boundary resources: } \\
\text { the case of apple's iOS } \\
\text { service system }\end{array}$ & $\begin{array}{l}\text { Eaton, Elaluf- } \\
\text { Calderwood } \\
\text { \& Sørensen }\end{array}$ & $\stackrel{n}{0}$ & $\begin{array}{l}\text { MIS } \\
\text { Quarterly }\end{array}$ & 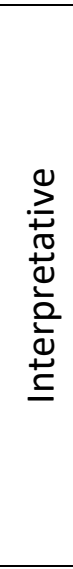 & $\begin{array}{l}\frac{7}{0} \\
\frac{0}{0} \\
\frac{\pi}{0} \\
\frac{0}{2} \\
\frac{2}{x}\end{array}$ & 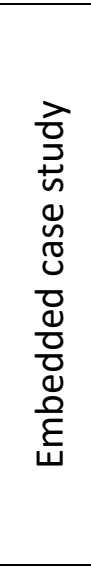 & $\begin{array}{l}\tilde{y} \\
\stackrel{0}{0} \\
\frac{0}{00} \\
\frac{0}{\infty}\end{array}$ & $\begin{array}{c}\text { Mass } \\
\text { collection of } \\
\text { qualitative } \\
\text { data from } \\
\text { social media } \\
\text { followed by } \\
\text { theoretical } \\
\text { sampling } \\
\text { informed by a } \\
\text { theoretical } \\
\text { framework }\end{array}$ & $\begin{array}{c}\text { Iterative } \\
\text { qualitative } \\
\text { coding informed } \\
\text { by a theoretical } \\
\text { framework }\end{array}$ & 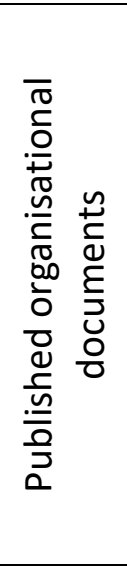 & z \\
\hline
\end{tabular}




\begin{tabular}{|c|c|c|c|c|c|c|c|c|c|c|c|}
\hline $\begin{array}{l}\text { Rethinking Lurking: } \\
\text { Invisible Leading and } \\
\text { Following in a } \\
\text { Knowledge Transfer } \\
\text { Ecosystem }\end{array}$ & $\begin{array}{l}\text { Cranefield, } \\
\text { Yoong, and } \\
\text { Huff }\end{array}$ & $\begin{array}{l}n \\
\stackrel{1}{0} \\
\end{array}$ & $\begin{array}{l}\text { Journal of } \\
\text { the } \\
\text { Associatio } \\
\mathrm{n} \text { for } \\
\text { Informatio } \\
\mathrm{n} \text { Systems }\end{array}$ & 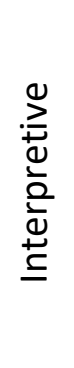 & 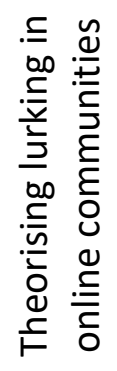 & 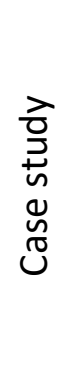 & 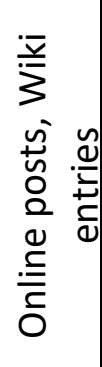 & $\begin{array}{c}\text { Multiple } \\
\text { phases of } \\
\text { data } \\
\text { collection } \\
\text { informed by a } \\
\text { theoretical } \\
\text { framework }\end{array}$ & $\begin{array}{l}\text { Inductive } \\
\text { analysis } \\
\text { informed by } \\
\text { grounded } \\
\text { theory }\end{array}$ & 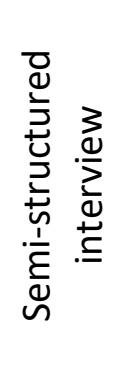 & ㅇ \\
\hline $\begin{array}{l}\text { ICT-Enabled Community } \\
\text { Empowerment in Crisis } \\
\text { Response: Social Media } \\
\text { in Thailand Flooding } \\
2011\end{array}$ & $\begin{array}{l}\text { Leong Mei } \\
\text { Ling, Pan, } \\
\text { Ractham, } \\
\text { and } \\
\text { Kaewkitipon } \\
g\end{array}$ & $\begin{array}{l}\tilde{n} \\
\stackrel{\sim}{\sim} \\
\text { | }\end{array}$ & $\begin{array}{l}\text { Journal of } \\
\text { the } \\
\text { Associatio } \\
\mathrm{n} \text { for } \\
\text { Informatio } \\
\mathrm{n} \text { Systems }\end{array}$ & 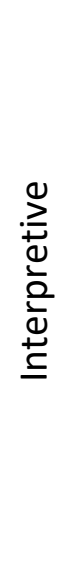 & $\begin{array}{l}\frac{1}{0} \\
0 \\
\frac{0}{0} \\
\frac{0}{2} \\
\frac{1}{x}\end{array}$ & 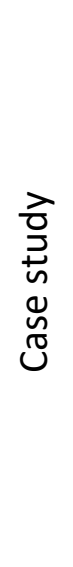 & 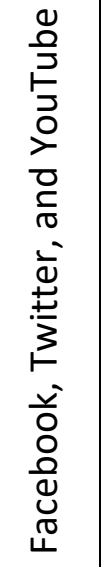 & $\begin{array}{c}\text { Multiple } \\
\text { phases of } \\
\text { data } \\
\text { collection } \\
\text { informed by a } \\
\text { theoretical } \\
\text { framework }\end{array}$ & $\begin{array}{c}\text { Thematic } \\
\text { qualitative } \\
\text { coding informed } \\
\text { by a theoretical } \\
\text { framework }\end{array}$ & 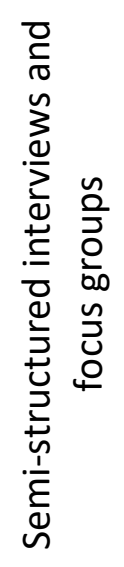 & ㅇ \\
\hline
\end{tabular}




\begin{tabular}{|c|c|c|c|c|c|c|c|c|c|c|c|}
\hline $\begin{array}{l}\text { A design theory for } \\
\text { digital platforms } \\
\text { supporting online } \\
\text { communities: a multiple } \\
\text { case study }\end{array}$ & $\begin{array}{l}\text { Spagnoletti1, } \\
\text { Resca, and } \\
\text { Lee }\end{array}$ & $\stackrel{\text { ñ }}{\circ}$ & $\begin{array}{l}\text { Journal of } \\
\text { Informatio } \\
n \\
\text { Technolog } \\
y\end{array}$ & 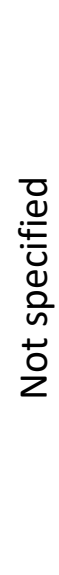 & 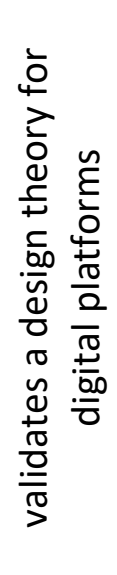 & 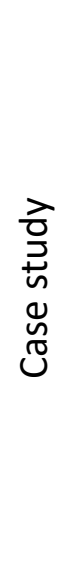 & 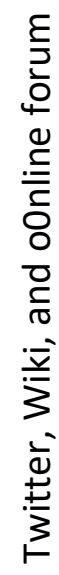 & $\begin{array}{l}\text { Multiple } \\
\text { phases of } \\
\text { data } \\
\text { collection } \\
\text { informed by a } \\
\text { theoretical } \\
\text { framework }\end{array}$ & $\begin{array}{c}\text { Iterative } \\
\text { analysis of } \\
\text { qualitative data }\end{array}$ & 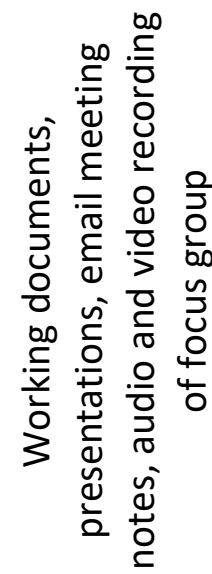 & ㅇ \\
\hline $\begin{array}{l}\text { Role of Social Media in } \\
\text { Social Change: An } \\
\text { Analysis of Collective } \\
\text { Sense Making During } \\
\text { the } 2011 \text { Egypt } \\
\text { Revolution }\end{array}$ & $\begin{array}{l}\text { Oh, Eom, } \\
\text { and Rao }\end{array}$ & $\stackrel{n}{\circ}$ & $\begin{array}{l}\text { Informatio } \\
n \text { Systems } \\
\text { Research }\end{array}$ & 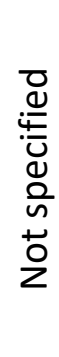 & $\begin{array}{l}\frac{1}{0} \\
+0 \\
\frac{0}{0} \\
\frac{0}{2} \\
\frac{2}{x}\end{array}$ & 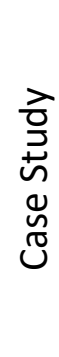 & $\stackrel{+}{\stackrel{ \pm}{ \pm}}$ & $\begin{array}{l}\text { Mass } \\
\text { collection of } \\
\text { qualitative } \\
\text { and } \\
\text { quantitative } \\
\text { data from } \\
\text { social media }\end{array}$ & $\begin{array}{c}\text { Thematic } \\
\text { analysis of } \\
\text { qualitative data }\end{array}$ & 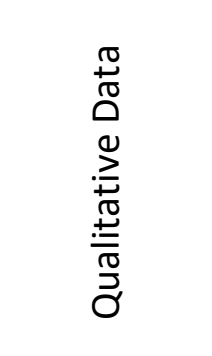 & ㅇ \\
\hline
\end{tabular}




\begin{tabular}{|c|c|c|c|c|c|c|c|c|c|c|c|}
\hline $\begin{array}{l}\text { Digital action } \\
\text { repertoires and } \\
\text { transforming a social } \\
\text { movement organization }\end{array}$ & $\begin{array}{l}\text { Selander and } \\
\text { Jarvenpaa }\end{array}$ & $\begin{array}{l}\text { 音 } \\
\text { N }\end{array}$ & $\begin{array}{l}\text { MIS } \\
\text { Quarterly }\end{array}$ & 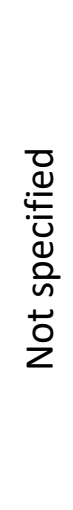 & 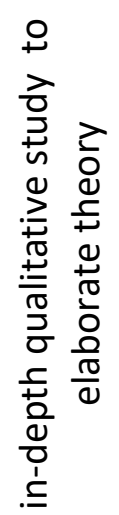 & 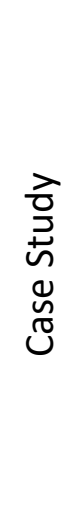 & 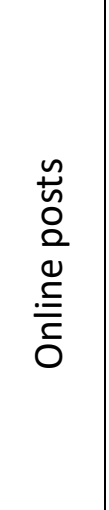 & $\begin{array}{l}\text { Multiple } \\
\text { phases of } \\
\text { data } \\
\text { collection } \\
\text { informed by a } \\
\text { theoretical } \\
\text { framework }\end{array}$ & $\begin{array}{l}\text { Multi-phase } \\
\text { inductive } \\
\text { analysis } \\
\text { informed by } \\
\text { grounded } \\
\text { theory }\end{array}$ & 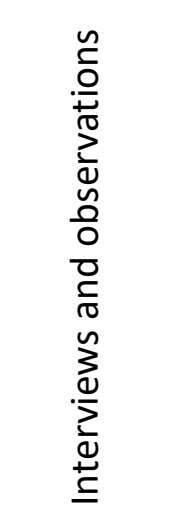 & 2 \\
\hline $\begin{array}{l}\text { Are social media } \\
\text { emancipatory or } \\
\text { hegemonic? societal } \\
\text { effects of mass media } \\
\text { digitization in the case } \\
\text { of the SOPA discourse }\end{array}$ & $\begin{array}{l}\text { Miranda, } \\
\text { Young, and } \\
\text { Yetgin }\end{array}$ & $\begin{array}{l}\text { 音 } \\
\text { N }\end{array}$ & $\begin{array}{l}\text { MIS } \\
\text { Quarterly }\end{array}$ & 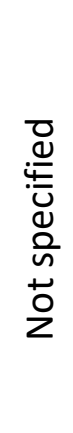 & 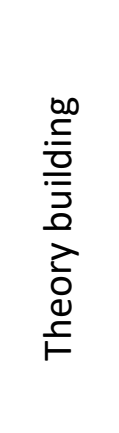 & 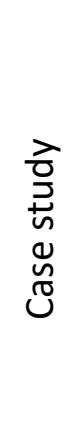 & 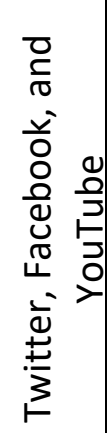 & $\begin{array}{c}\text { Multiple } \\
\text { phases of } \\
\text { data } \\
\text { collection } \\
\text { informed by a } \\
\text { theoretical } \\
\text { framework }\end{array}$ & $\begin{array}{c}\text { Iterative } \\
\text { qualitative } \\
\text { coding informed } \\
\text { by a theoretical } \\
\text { framework }\end{array}$ & 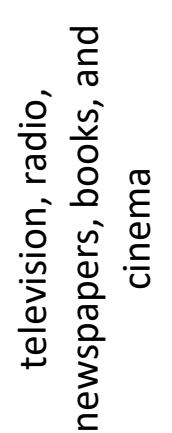 & 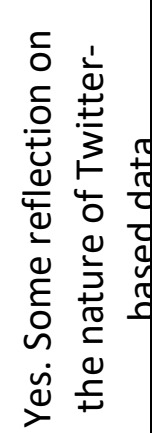 \\
\hline
\end{tabular}




\begin{tabular}{|c|c|c|c|c|c|c|c|c|c|c|c|}
\hline $\begin{array}{l}\text { Digitally enabled } \\
\text { disaster response: the } \\
\text { emergence of social } \\
\text { media as boundary } \\
\text { objects in a flooding } \\
\text { disaster }\end{array}$ & $\begin{array}{l}\text { Tim, Pan, } \\
\text { Ractham, } \\
\text { Kaewkitipon } \\
g\end{array}$ & $\begin{array}{l}0 \\
\stackrel{\sim}{N}\end{array}$ & $\begin{array}{l}\text { Informatio } \\
\text { n Systems } \\
\text { Journal }\end{array}$ & 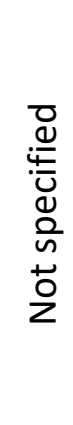 & $\begin{array}{l}\frac{7}{0} \\
+0 \\
\frac{0}{0} \\
\frac{0}{0} \\
\frac{0}{x}\end{array}$ & 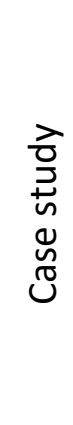 & 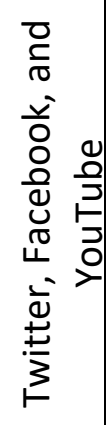 & $\begin{array}{l}\text { Multiple } \\
\text { phases of } \\
\text { data } \\
\text { collection } \\
\text { informed by a } \\
\text { theoretical } \\
\text { framework }\end{array}$ & $\begin{array}{c}\text { Iterative } \\
\text { analysis of } \\
\text { qualitative data }\end{array}$ & 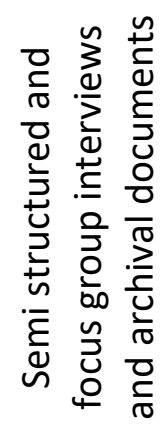 & zo \\
\hline $\begin{array}{l}\text { Knowledge } \\
\text { entrepreneurship: } \\
\text { institutionalising wiki- } \\
\text { based knowledge } \\
\text { management processes } \\
\text { in competitive and } \\
\text { hierarchical } \\
\text { organisations }\end{array}$ & $\begin{array}{l}\text { Argyris and } \\
\text { Ransbotham }\end{array}$ & $\stackrel{0}{\circ}$ & $\begin{array}{l}\text { Journal of } \\
\text { Informatio } \\
n \\
\text { Technolog } \\
y\end{array}$ & $\begin{array}{l}\stackrel{0}{ \pm} \\
\stackrel{0}{0} \\
\stackrel{0}{0} \\
\stackrel{0}{ \pm}\end{array}$ & 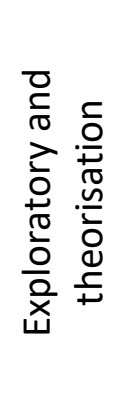 & 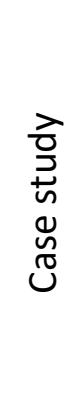 & $\stackrel{י}{\overrightarrow{3}}$ & $\begin{array}{l}\text { Multiple } \\
\text { phases of } \\
\text { data } \\
\text { collection } \\
\text { informed by a } \\
\text { theoretical } \\
\text { framework }\end{array}$ & $\begin{array}{c}\text { Iterative } \\
\text { analysis of } \\
\text { qualitative data }\end{array}$ & 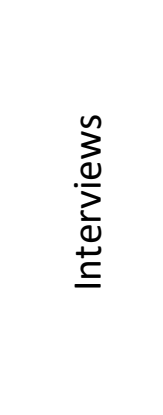 & $\stackrel{0}{z}$ \\
\hline $\begin{array}{l}\text { Affordances of social } \\
\text { media in collective } \\
\text { action: the case of Free } \\
\text { Lunch for Children in } \\
\text { China }\end{array}$ & $\begin{array}{l}\text { Zheng and } \\
\text { Yu }\end{array}$ & $\begin{array}{l}\stackrel{0}{\Delta} \\
\stackrel{N}{N}\end{array}$ & $\begin{array}{l}\text { Informatio } \\
\text { n Systems } \\
\text { Journal }\end{array}$ & 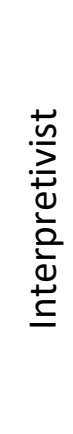 & 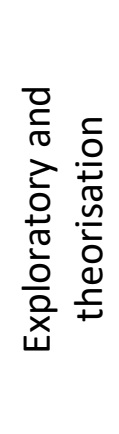 & 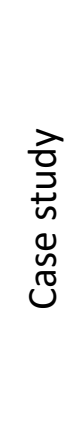 & 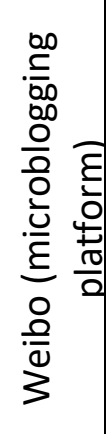 & $\begin{array}{l}\text { Multiple } \\
\text { phases of } \\
\text { data } \\
\text { collection } \\
\text { informed by a } \\
\text { theoretical } \\
\text { framework }\end{array}$ & $\begin{array}{c}\text { Iterative } \\
\text { analysis of } \\
\text { qualitative data }\end{array}$ & 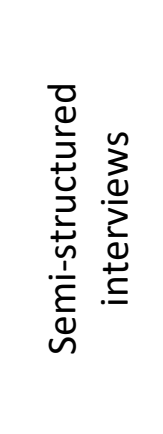 & 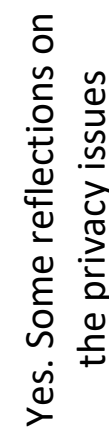 \\
\hline
\end{tabular}




\begin{tabular}{|c|c|c|c|c|c|c|c|c|c|c|c|}
\hline $\begin{array}{l}\text { Combining social media } \\
\text { affordances for } \\
\text { organising collective } \\
\text { action }\end{array}$ & $\begin{array}{l}\text { Sæb } \varnothing \text {, } \\
\text { Federici, and } \\
\text { Braccini }\end{array}$ & 亏े & $\begin{array}{l}\text { Informatio } \\
\text { n Systems } \\
\text { Journal }\end{array}$ & 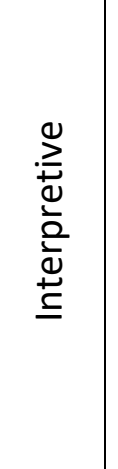 & $\begin{array}{l}\frac{2}{0} \\
+\frac{0}{0} \\
\frac{0}{2} \\
\frac{0}{x}\end{array}$ & 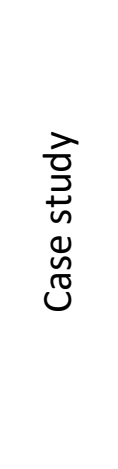 & 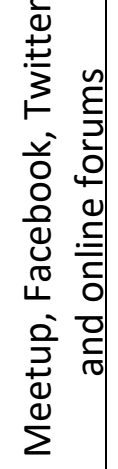 & $\begin{array}{l}\text { Multiple } \\
\text { phases of } \\
\text { data } \\
\text { collection } \\
\text { informed by a } \\
\text { theoretical } \\
\text { framework }\end{array}$ & $\begin{array}{l}\text { Inductive } \\
\text { analysis } \\
\text { informed by } \\
\text { grounded } \\
\text { theory }\end{array}$ & 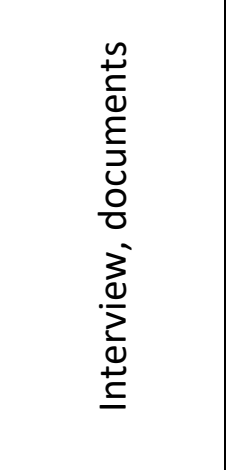 & 2 \\
\hline $\begin{array}{l}\text { Social media } \\
\text { affordances for } \\
\text { connective action: an } \\
\text { examination of } \\
\text { microblogging use } \\
\text { during the gulf of } \\
\text { Mexico oil spill1 }\end{array}$ & $\begin{array}{l}\text { Vaast } \\
\text { Safadi } \\
\text { Lapointe \& } \\
\text { Negoita }\end{array}$ & 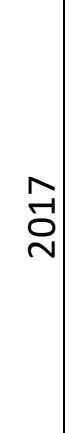 & $\begin{array}{l}\text { MIS } \\
\text { Quarterly }\end{array}$ & 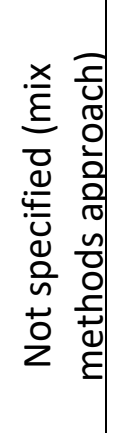 & 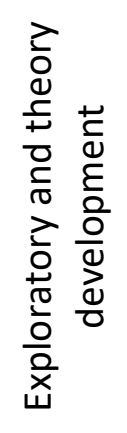 & 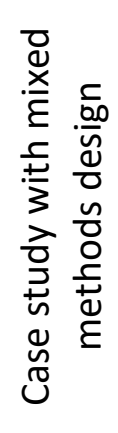 & 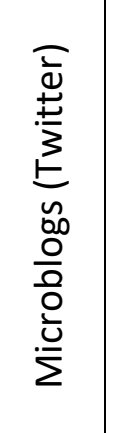 & $\begin{array}{l}\text { Theoretical } \\
\text { sampling } \\
\text { informed by } \\
\text { grounded } \\
\text { theory }\end{array}$ & $\begin{array}{l}\text { Iterative } \\
\text { analysis of } \\
\text { qualitative data } \\
\text { informed by } \\
\text { grounded } \\
\text { theory }\end{array}$ & $\stackrel{0}{2}$ & 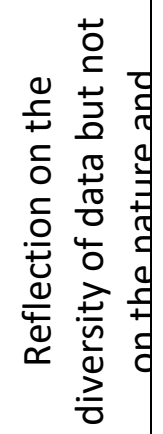 \\
\hline $\begin{array}{l}\text { Multiple social media in } \\
\text { the workplace: } \\
\text { Contradictions and } \\
\text { congruencies }\end{array}$ & $\begin{array}{l}\text { Forsgren and } \\
\text { Byström }\end{array}$ & $\overrightarrow{\hat{D}}$ & $\begin{array}{l}\text { Informatio } \\
\text { n Systems } \\
\text { Journal }\end{array}$ & 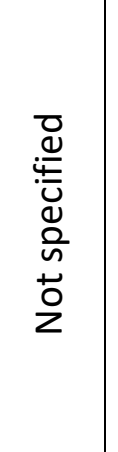 & $\begin{array}{l}\frac{2}{0} \\
+0 \\
\frac{0}{0} \\
\frac{0}{2} \\
\frac{x}{4}\end{array}$ & 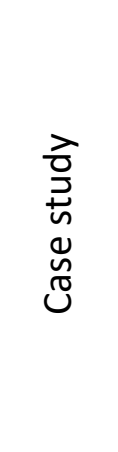 & 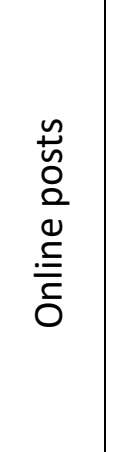 & $\begin{array}{c}\text { Multiple } \\
\text { phases of } \\
\text { data } \\
\text { collection } \\
\text { informed by a } \\
\text { theoretical } \\
\text { framework }\end{array}$ & $\begin{array}{l}\text { Iterative } \\
\text { analysis of } \\
\text { qualitative data } \\
\text { informed by } \\
\text { grounded } \\
\text { theory }\end{array}$ & 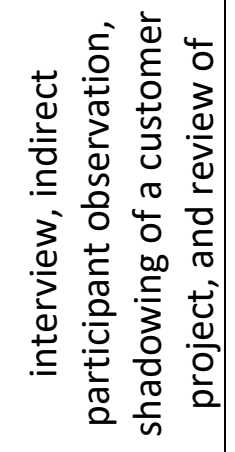 & 2 \\
\hline
\end{tabular}




\begin{tabular}{|c|c|c|c|c|c|c|c|c|c|c|c|}
\hline $\begin{array}{l}\text { An affordance } \\
\text { perspective of } \\
\text { enterprise social media } \\
\text { and organizational } \\
\text { socialization }\end{array}$ & $\begin{array}{l}\text { Leidner, } \\
\text { Gonzalez, } \\
\text { and Koch }\end{array}$ & $\stackrel{\infty}{\stackrel{0}{0}}$ & $\begin{array}{l}\text { Journal of } \\
\text { Strategic } \\
\text { Informatio } \\
n \text { Systems }\end{array}$ & 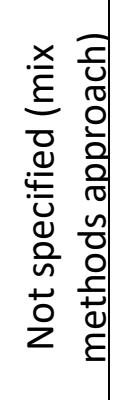 & 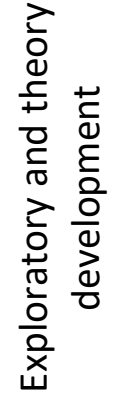 & 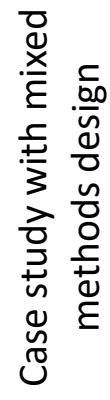 & $\begin{array}{l}\stackrel{n}{\tilde{n}} \\
\stackrel{0}{0} \\
00 \\
\frac{0}{\infty}\end{array}$ & $\begin{array}{l}\text { Multiple } \\
\text { phases of } \\
\text { data } \\
\text { collection } \\
\text { informed by a } \\
\text { theoretical } \\
\text { framework }\end{array}$ & $\begin{array}{c}\text { Iterative } \\
\text { analysis of } \\
\text { qualitative data }\end{array}$ & 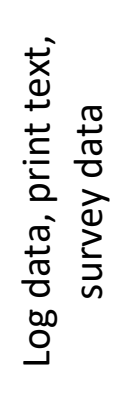 & 운 \\
\hline $\begin{array}{l}\text { The anonymous online } \\
\text { self: Toward an } \\
\text { understanding of the } \\
\text { tension between } \\
\text { discipline and online } \\
\text { anonymity }\end{array}$ & Guo and $Y u$ & $\stackrel{\text { }}{\stackrel{\mathcal{O}}{\sim}}$ & $\begin{array}{l}\text { Informatio } \\
\text { n Systems } \\
\text { Journal }\end{array}$ & 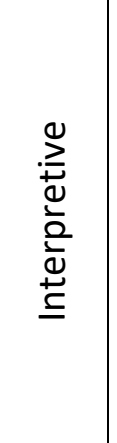 & 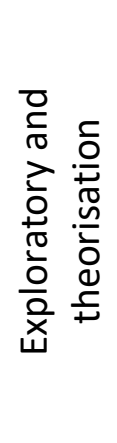 & 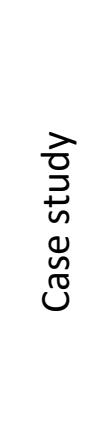 & 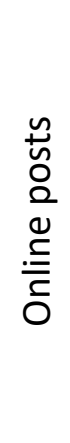 & $\begin{array}{l}\text { Mass } \\
\text { collection of } \\
\text { qualitative } \\
\text { data from } \\
\text { social media }\end{array}$ & $\begin{array}{l}\text { Inductive } \\
\text { analysis } \\
\text { informed by } \\
\text { grounded } \\
\text { theory }\end{array}$ & i & 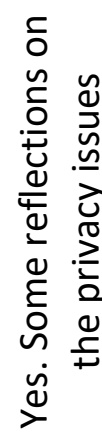 \\
\hline $\begin{array}{l}\text { "I Am Your Fan; } \\
\text { Bookmarked!" } \\
\text { Members' Identification } \\
\text { Development in } \\
\text { Founder-Led Online } \\
\text { Communities }\end{array}$ & $\begin{array}{l}\text { Panteli1 and } \\
\text { Sivunen }\end{array}$ & $\stackrel{9}{0}$ & $\begin{array}{l}\text { Journal of } \\
\text { the } \\
\text { Associatio } \\
\mathrm{n} \text { for } \\
\text { Informatio } \\
\mathrm{n} \text { Systems }\end{array}$ & 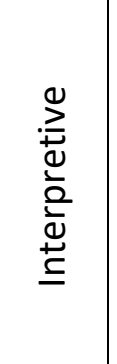 & $\begin{array}{l}\frac{1}{0} \\
\frac{1}{\pi} \\
\frac{0}{0} \\
\frac{0}{2} \\
\dot{x}\end{array}$ & 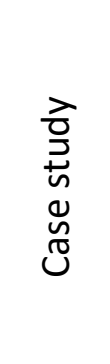 & 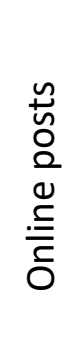 & $\begin{array}{l}\text { Multiple } \\
\text { phases of } \\
\text { data } \\
\text { collection } \\
\text { informed by } \\
\text { grounded } \\
\text { theory }\end{array}$ & $\begin{array}{l}\text { Inductive } \\
\text { analysis } \\
\text { informed by } \\
\text { grounded } \\
\text { theory }\end{array}$ & ㅇ & 2 \\
\hline
\end{tabular}




\begin{tabular}{|c|c|c|c|c|c|c|c|c|c|c|c|}
\hline $\begin{array}{l}\text { Social media } \\
\text { empowerment in social } \\
\text { movements: power } \\
\text { activation and power } \\
\text { accrual in digital } \\
\text { activism }\end{array}$ & $\begin{array}{l}\text { Leong, Pan, } \\
\text { Bahri \& Fauzi }\end{array}$ & 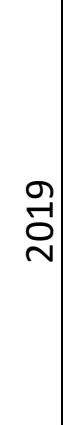 & $\begin{array}{l}\text { European } \\
\text { Journal of } \\
\text { Informatio } \\
n \text { Systems }\end{array}$ & 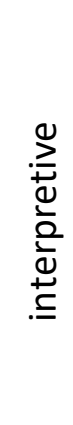 & $\begin{array}{l}\frac{7}{0} \\
\frac{0}{0} \\
\frac{\pi}{0} \\
\frac{0}{2} \\
\frac{0}{x}\end{array}$ & 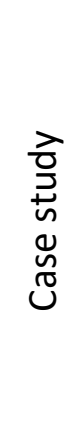 & 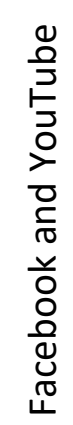 & $\begin{array}{l}\text { Multiple } \\
\text { phases of } \\
\text { data } \\
\text { collection } \\
\text { informed by a } \\
\text { theoretical } \\
\text { framework }\end{array}$ & $\begin{array}{c}\text { Iterative } \\
\text { analysis of } \\
\text { qualitative data }\end{array}$ & 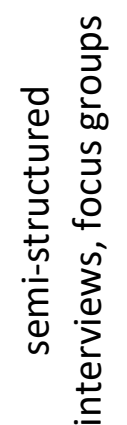 & 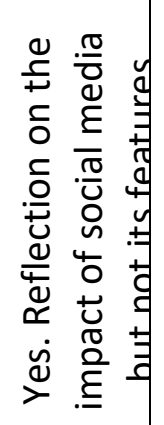 \\
\hline
\end{tabular}

